\title{
Tobacco Industry Influence
}

The origins of the tobacco market can be traced back to the seventeenth century. The famous Dutch golden age was an era of prosperity for tobacco merchants. They traded not only in spices and slaves but also in tobacco, and made Dutch towns extremely wealthy and financed the famous grand houses lining the canals of Amsterdam today. The habit of smoking tobacco spread from the New World and from England to the Dutch harbours. The act of smoking can be seen on many Dutch paintings from the seventeenth century. According to historian Schama (1987, p. 189), in the Golden Age "the smell of the Dutch Republic was the smell of tobacco." He referred to accounts by visitors to the Netherlands who were struck by the omnipresence of tobacco smoke in inns and towing barges, and the common sight of men and women smoking in public. Dutch clay pipes became an important export product. In the first half of the seventeenth century, tobacco was imported from the Americas, processed in Amsterdam, and exported to Russia and the Baltic. Amsterdam was the biggest staple market for Virginia and Maryland tobacco. The Dutch tobacco trade received a further boost when merchants set up tobacco plantations on Dutch soil, especially in the middle of the country, around the city of Amersfoort, and in the province of Gelderland. Around the year 1700 the total volume of exported mixed tobacco to Denmark, Sweden, Russia, and the Baltic states was about 10-15 million pounds per year,

(C) The Author(s) 2018

M. C. Willemsen, Tobacco Control Policy in the Netherlands, Palgrave Studies in Public Health Policy Research, https://doi.org/10.1007/978-3-319-72368-6_8 
much larger than the 1.2 million that England exported to the Nordic countries (Roessingh, 1976).

Tobacco was still a thriving local agricultural and manufacturing sector in the Netherlands in the nineteenth century, after which the country gradually became the playground of a few multinational companies in the twentieth century. By the 1980s the Dutch tobacco industry had become an oligopoly, with two companies (Imperial Tobacco and British American Tobacco) dominating the roll-your-own market and four companies (BAT, Imperial Tobacco, Japan Tobacco International, and Philip Morris) dominating the cigarette and cigar market. They had selected the Low Countries as an international stronghold, and the Netherlands became one of the largest tobacco exporting countries in the world. This made the industry difficult to regulate because it was relatively powerful: it did not stand alone in its fight against regulators, but was supported by a network of allies with a common interest in protecting the status quo concerning selling tobacco, or who shared a common libertarian ideology. In this chapter I describe how the tobacco industry organised its lobbying apparatus, followed by a discussion of tobacco industry media advocacy to sway public opinion about passive smoking and attempts at influencing tobacco control through the ministries and the parliament.

\section{Tobacco Manufacturers Join Forces}

Organised national tobacco industry lobbies developed sooner than organised tobacco control lobbies. In 1952 the manufacturers of rollyour-own tobacco joined forces and founded the Vereniging Nederlandse Kerftabakindustrie (Dutch Fine Cut Tobacco Industry Association) (VNK). Three years later cigarette manufacturers followed their example and founded the Stichting Sigaretten Industrie (Dutch Cigarette Manufacturers Association) (SSI). VNK and SSI shared the same lobbying apparatus, including communal office space in The Hague. Both employed one lobbyist and one supporting staff member. In 2017, VNK and SSI merged into one organisation: the Vereniging Nederlandse Sigaretten-en Kerftabakfabrikanten (Association for Dutch Cigarette and Fine Cut Tobacco Manufacturers) (VSK). The interests of Dutch cigar manufacturers are represented by the Nederlandse Vereniging voor de Sigarenindustrie (Dutch Cigar Industry Association) (NVS), established in 1971. Important allies of the tobacco manufacturers who share an economic interest in tobacco are the retail, wholesale, and vending machine sectors. Tobacco 
lobbyists sometimes refer to their closest allies as belonging to "the tobacco family" (Philip Morris, 1979). For many years the tobacco retail sector had two interest groups: a general and a Catholic. They merged in 1974 into the Dutch tobacco retail organisation Nederlandse Sigarenverkopers Organisatie (Dutch Cigar Sale Organisation) (NSO). Since 1996, motivated by the threat of legal restrictions on the sale of tobacco, the tobacco distributers and exploiters of tobacco vending machines united in a separate lobbying group, Landelijke Belangenvereniging van Tabaksdistributeurs Nederland (National Association for Tobacco Distributors) (LBT) (Van Oosten, 1996). Around that time the tobacco retailers also set up an organisation to coordinate activities related to implementing age of sale restrictions (the PVT).

VNK, SSI, NVS, and NSO were (and still are) natural allies when it came to the wish to normalise smoking and to prevent government regulation, but they were also competitors, driven by material self-interest. The VNK wanted to retain low taxation levels for roll-your-own products, while the SSI and Philip Morris, with little interest in the roll-your-own market, lobbied to reduce the tax gap between roll-your-own and factory made cigarettes. The NSO fought with BAT over the size of the retail margins on tobacco products sold in shops. The individual manufacturers have divergent interests and different views on lobbying strategy. Philip Morris stepped out of the SSI in 2005 because as market leader it could protect its interests better without needing to consult with the other tobacco producers. ${ }^{1}$

\section{SCIENTISTS FOR Hire}

In 1964 the SSI set up the Wetenschappelijke Adviesraad Roken en Gezondheid (Scientific Advisory Council on Smoking and Health) (WARG) to counteract the health concerns that emerged after the first reports on smoking and health from the United States and the United Kingdom. WARG received large sums of money from the SSI to initiate scientific research into the effects of tobacco smoke on the lungs, much of it carried out at the CIVO in Zeist, part of Nederlandse Organisatie voor Toegepast Natuurwetenschappelijk Onderzoek (Netherlands Organisation for applied scientific research) (TNO). Some research money was also accepted by the Dutch Cancer Institute at the Antoni van Leeuwenziekenhuis (Emmelot, 1979; RJ Reynolds, 1978); in these years the tobacco industry was not yet widely regarded as morally "bad." After 15 years, WARG had published 
some 34 reports, 17 international scientific articles, and $1 \mathrm{PhD}$ dissertation. Most of the research by WARG scientists was about reducing the carcinogenicity of tobacco smoke and determining acceptable threshold levels for exposure (Vossenaar, 1997). From 1973 onwards WARG operated a documentation centre that collected international scientific papers on smoking and health issues. Lists of selected publications with photocopies and summaries were widely distributed, finding their way to officials at the Ministry of Health (Emmelot, 1979). In 1979 alone, 46 such lists were distributed. WARG was disbanded in 1997, one year after the British Medical Journal and The Lancet declared that research funded by the tobacco industry would no longer be published. We do not know exactly how effective industry publications were in influencing the attitude of politicians and government officials towards the smoking problem, but it is likely that they contributed to some of the hesitance to act in these early years.

Recruitment of scientists continued after the disbandment of WARG. Philip Morris wanted to hold off smoking restrictions and started a concerted campaign "to prevent the imposition of smoking restrictions (...) based on the asserted health hazards of ETS to non-smokers. To realize this objective, three audiences had to be convinced that the health claims by anti-smoking forces concerning ETS were groundless. Those three audiences were the scientific community, regulatory authorities, and the general public" (Remes, 1988, p. 1). The strategy was to find scientists "who can attack the studies relied on by the anti-smoking forces to justify smoking restrictions on health grounds" (Remes, 1988, p. 1). At the core of the Philip Morris strategy was "mobilising in each market a corps of scientific consultants and engineers who can make the scientific case against smoking restrictions through articles in scientific journals and presentations at scientific conferences and symposia, through articles and interviews in the mass media, and through meetings with and appearances before regulatory authorities" (Remes, 1988, p. 2).

Philip Morris had some success in recruiting Dutch scientists. In 1993 a report from the US Environmental Protection Agency (EPA, 1992) attracted attention in the Netherlands. Toxicologist Freek de Wolff criticised the US Environmental Protection Agency (EPA) report (De Wolff, 1994b). De Wolff had served as an expert witness for Philip Morris, testifying against proposed rules on indoor air quality in the United States (De Wolff, 1994a), and had produced a report for Philip Morris with arguments against a European Union (EU) Directive that obliged the Dutch 
tobacco industry to declare the ingredients in their products (Wigand, 2005). Publications such as this made it easy for politicians to ignore the call for a workplace smoking ban, since they could label it a controversial issue with no apparent consensus on whether it was a problem important enough for the government to address.

Another attempt to normalise smoking was through Associates for Research into the Science of Enjoyment (ARISE), an industry-funded group of researchers. ARISE, active between 1988 and 1999, produced scientific papers and academic books promoting the idea that smoking is a harmless "everyday pleasure" comparable to drinking coffee or eating chocolate, improving the quality of life and reducing everyday stress (Elizabeth A. Smith, 2007). In 1995 ARISE held a conference in Amsterdam (ARISE, 1995b). The closing recommendation included the text, "people should live a life of moderate hedonism, so that they can live to the full the only life they are ever likely to have." The call to enjoy pleasures such as smoking without guilt received some positive press coverage in Dutch newspapers (ARISE, 1995a).

\section{How the Industry Prevented Smoking Bans}

By far the toughest battle between tobacco control advocates and the tobacco industry network was over smoking bans, a fight that started some 30 years ago. By the end of the 1980s most of the epidemiological evidence from international research supported the claim that passive smoking is harmful and causes lung cancer. Reports by the federal government of the United States, Australia, and WHO fuelled calls for better protection of non-smokers (National Research Council, 1986; O'NeillI, Brunnemann, Dodet, \& Hoffmann, 1987; US Surgeon General, 1986). It was crucial for the industry's marketers to understand in which countries the threat of smoking bans was most imminent. In 1997 and 1998 Philip Morris collected public opinion data in all 57 countries where they were active. Representative samples of people in each were asked what they thought about the harm from passive smoking and whether they supported government regulations (GfK Great Britain, 1998). The researchers found that respondents were much more likely to support smoking restrictions when they were living in countries where there was more public concern about the health risks of ETS. The correlation coefficient was 0.72 , quite high for this type of research. They also found an association between annoyance from second-hand smoke and the belief that smoking 
in public places is seen as a priority for governments. The level of felt annoyance in the Netherlands ranked remarkably low among the 37 countries where this item was measured: only $26 \%$ of Dutch non-smokers were "very annoyed" by people smoking around them. This suggested a high level of tolerance to smoking. Only Denmark was more tolerant (16\%). The least tolerant were Greece (62\%), Italy (57\%), Ireland (45\%), and the United Kingdom (45\%). The industry used such data to tailor its normalisation efforts on a country-to-country basis. For the Netherlands, as tolerance was already high, it only needed to be boosted by tobacco normalising campaigns. In 1985 the SSI established a small professional communication bureau, the Voorlichtingsbureau Sigaretten en Shag (Cigarettes and Roll-your-own tobacco Education Bureau), renamed Bureau Voorlichting Tabak (Tobacco Education Bureau) (BVT) in 1994. This bureau was responsible for campaigns designed to influence public opinion about passive smoking (Table 8.1).

Through these campaigns, year after year, the public and politicians were bombarded with a simple message: smokers have the right to enjoy smoking and this should be tolerated and respected, not repressed. Such messages were well received by the Netherlands' pluralistic and permissive society.

In addition, Philip Morris ran programmes to accommodate smokers by either setting up smoking sections ("courtesy of choice" programmes) or promoting ventilation technology when separation was not possible. This started in 1995 in an effort to prevent smoking bans in public transport, the hospitality sector, and workplaces. In an internal memo,

Table 8.1 Tobacco industry tolerance campaigns in the Netherlands

\begin{tabular}{|c|c|}
\hline Year & Campaign (translated from Dutch) \\
\hline 1978 & Poster campaign "friendly smoking" targeted at city councils \\
\hline 1984 & $\begin{array}{l}\text { Campaign "There are smokers and non-smokers. Take each other into } \\
\text { consideration" }\end{array}$ \\
\hline 1984 & $\begin{array}{l}\text { Letter campaign to parliamentarians and city councils "Smoking ... a } \\
\text { matter of give and take" }\end{array}$ \\
\hline 1984 & Brochure to family physicians "Information about smoking and society" \\
\hline 1985-1987 & Campaign "Smoking must be permitted" \\
\hline 1991 & Campaign "Smoking? We work it out together" \\
\hline 1992 & "Smoking as usual. Or not. We keep it sociable" \\
\hline 1995 & Campaign "Enjoyment must be permitted" \\
\hline 1999 & Campaign "Smoking? Ask for permission!" \\
\hline
\end{tabular}


industry representatives wrote that by 1999 such programmes had been rather successful:

By any measure, the International Accommodation Program is very effective. This programme operates in 46 countries and more than 6600 establishments, is growing at $50 \%$ per year, has been used repeatedly to prevent or modify smoking restrictions, has generated no negative reaction, and effective coalitions have been built with the hospitality industry. (Goldberg, 1999b, p. 2074399558)

The memo further mentioned that the programmes in the Netherlands were "used by the Dutch hospitality industry to maintain a reasonable attitude. Courtesy of Choice is in operation in the Dutch Parliament in The Hague" (Goldberg, 1999b, p. 2074395548). Philip Morris had indeed organised smoking sections in the restaurant of the Dutch parliament building. This was a deliberate attempt to get to politicians, "another simple, yet very effective, strategy ... to target places of influence" (Goldberg, 1999a, p. 2). What is remarkable is that the memo mentioned only the Dutch, Belgian, and EU parliament buildings in Brussels and Strasbourg, suggesting that the Dutch parliament was either an easy or an important target, or both.

While industry campaigns were well received in the 1980s and strengthened societal norms that smoking in public must be tolerated in the Netherlands, in the 1990s they were gradually losing the fight over smoking in public. Box 8.1 gives an example of how Philip Morris unsuccessfully attempted to sway public opinion on the risks of passive smoking during a time that passive smoking was already widely regarded as harmful.

Box 8.1 Philip Morris' failed “cookies campaign"

In June 1996 Philip Morris launched a Europe-wide attack on the growing concern about passive smoking. It ran large newspaper ads in nine European countries with the headline, "Second-hand tobacco smoke in perspective." Page-wide advertisements downplayed the risk from passive smoking by comparing it to presumed risks associated with drinking chlorinated tap water, consuming cookies, or eating hot pepper. The campaign was strongly condemned by Padraig 
Flynn, the EU commissioner for health matters, and international health organisations challenged the campaign in court. The Union for International Cancer Control, a main European tobacco control lobbying organisation, faxed a document with a warning regarding the press release of the Philip Morris campaign and a detailed rebuttal of the claims that Philip Morris made in the advertisement to the Stichting Volksgezondheid en Roken (Dutch Smoking or Health Foundation) (STIVORO) (UICC, 1996). STIVORO was thus well prepared when Philip Morris presented the campaign at a press conference in The Hague, and on the day the campaign was launched issued a press statement in which STIVORO's director criticised the campaign to the press outside the conference room, claiming that the campaign was misleading (Nellen \& De Blij, 1999). Health Minister Borst communicated the same message in reply to questions by parliament and through a press statement. ${ }^{2}$ Dutch health organisations complained to the Advertising Control Board. Two weeks after the campaign started, Philip Morris had to withdraw the campaign prematurely.

Although it resulted in bad publicity for Philip Morris, and even brought them in conflict with other tobacco manufacturers, the "cookies campaign" still had some effect on Dutch public opinion regarding harm from passive smoking. According to survey data collected by STIVORO, before the campaign $60 \%$ of the Dutch believed that ETS could cause lung cancer, and this was $57 \%$ after the campaign (Nellen \& De Blij, 1999). Research commissioned by Philip Morris showed that the proportion of Dutch who believed that environmental tobacco smoke was "a serious health risk" had gone down, from $21 \%$ to $18 \%$ (Wirthlin Group, 1996). However, the STIVORO survey showed that general public support for smoking bans had significantly increased, suggesting that the main goal of the campaign had failed. According to STIVORO, the campaign had "antagonised the Dutch government and the Health Commission of the European parliament ... it is likely that the campaign helped to reduce the tobacco industry's political and public support" (Nellen \& De Blij, 1999, p. 222). 


\section{The Employers' Organisation VNO-NCW}

A key supporter of the tobacco industry was the national employers interest organisation Verbond van Nederlandse Ondernemingen en Nederlands Christelijk Werkgeversverbond (Confederation of Netherlands Industry and Employers) (VNO-NCW). It was and is arguably the most powerful Dutch lobbying organisation. The three main Dutch tobacco lobby organisations (SSI, VNK, and NVS) have seats on its general board (Braam \& Van Woerden, 2013) and its director is widely considered one of the most influential people in the country. According to Hans Hillen, former Christen-Democratisch Appèl (Christian Democratic Party) (CDA) senator, ex-minister for defence, and former advisor to British American Tobacco, "Everyone at a high position needs at least ten years to understand how Dutch governance works. Very few people have really mastered this and Niek Jan [van Kesteren] controls it to perfection. He is the spider in the web" (Van de Wetering, 2010). Some have called him the emperor of the polder (Korteweg \& Huisman, 2016). In an interview, van Kesteren disclosed that all branch organisations in the tobacco sector regularly meet at $\mathrm{VNO}-\mathrm{NCW}$ to discuss lobbying strategies (Braam \& Van Woerden, 2013): "We are one of the few friends the tobacco industry has." VNONCW has a Brussels office and played a major role in opposing the revised Tobacco Products Directive (TPD-2). VNO-NCW preferably lobbies "through the inner line. The more silently, the better" (Andeweg \& Irwin, 2009, p. 15). The Truth Tobacco Industry Documents database ${ }^{3}$ contains many examples of letters from VNO-NCW on tobacco policy to Dutch government officials, including ministers. One example is a set of personal letters from VNO-NCW's Chairman Alexander Rinnooy $\mathrm{Kan}^{4}$ to the minister for economic affairs and the minister for health in 1994 and 1995, pleading for self-regulation instead of a ban on tobacco advertising (Rinnooy-Kan, 1994, 1995a, 1995b).

\section{Industry-Friendly Politicians}

Lobbying through parliament is known as "the royal way," since it involves the instruments of democracy. CDA parliamentarian Wim van de Camp said in 1999, "The professionalism of the tobacco lobby in The Hague is remarkable. A strong, polished lobby, not obtrusive, very well organised. They monitor everything that is happening in the parliament quite well" (Bouma, 2012). If direct lobbying through contacts within the bureaucracy 
does not work, the industry puts pressure on the government through industry-friendly politicians who are willing to ask parliamentary questions. The one party that the industry can rely on to be generous in voicing concerns is the conservative-liberal Volkspartij voor Vrijheid en Democratie (People's Party for Freedom and Democracy) (VVD). VVD connections with the industry have been, and still are, close: for example, Ferry Houterman, political advisor to several VVD ministers, was supervisory director at Philip Morris for some years (Luyendijk, Verkade, \& Heck, 2010). In the past VVD motions have often been supported by other liberal factions in parliament, especially the Partij voor de Vrijheid (Freedom Party) (PVV), and sometimes by Democraten 66 (Democrats 66) (D66) and the CDA as well. These parties are in many ways different, but they share the values of preserving individual lifestyle choices and concerns that reducing the tobacco sector might result in negative consequences for (small) businesses.

The position of the CDA, a party occupying the middle of the political spectrum, is nuanced. Typical for the CDA approach is to advance tobacco control in small steps, taking the interests of small businesses into consideration. The CDA is ideologically conservative in that it usually opposes too much government interference, especially if it feels that an issue can be resolved by other means. The CDA played a key role in the tobacco industry lobby against legislation until the mid-1990s, and because it held strategic positions in ruling coalitions for many years it was an ideal vehicle for the industrial lobby. The CDA was always part of ruling coalitions, except in the Purple cabinets (1994-2002) and the Rutte II cabinet (2012-2017). Prominent CDA politician Joost van Iersel is often quoted for his remark in the 1980s: "We just run this country." One former civil servant remarked about the CDA in the 1980s and first half of the 1990s, "That was the old CDA of Lubbers and Brinkman who had close ties with VNO-NCW and Philip Morris, and who were against legislation." ${ }^{5}$ Many key persons in the tobacco industry network were prominent members of the CDA. VNO-NCW Director Niek Jan van Kesteren and the various chairs of VNO-NCW were influential CDA members, and allowed the tobacco industry direct access to other powerful CDA people such as Fons van der Stee (Minister for Finance 1973-1982), Elco Brinkman (Minister for Health 1982-1989), Ab Klink (Minister for Health 2007-2010), and Prime Ministers Ruud Lubbers (1982-1994) and Jan Peter Balkenende (2002-2007). One ex-civil servant remembered how Health Minister 
Ab Klink was played: "Niek-Jan van Kesteren phoned at the merest trifle. He had a hotline with Ab Klink, so to say. And what was the effect? That $\mathrm{Ab}$ inserted the idea of the parallel interests into the [tobacco] nota. That was all the doing of Niek-Jan van Kesteren."6

Former Health Minister Elco Brinkman was leader of the CDA faction in the second chamber of parliament from 1989 until 1994, and has been in the senate since 2011. Brinkman is a firm free-market proponent, very well connected in the business world. He explained in an interview why he believed that smoking should not be regulated: he was brought up "with a way of thinking that emphasises people's individual responsibility. I believe that smoking is a personal decision. Moreover, tobacco is a legal product." These convictions reflect the core beliefs that are binding factors for the various parties in the tobacco network. Later in his political career he became commissioner for Philip Morris and vice president of VNO-NCW. In 2009 Brinkman helped the industry to change the official standpoint of the minister for finance about minimum cigarette prices in Europe. ${ }^{8}$ There were also links between the industry and the CDA in Parliament. For example, Jan Schipper, a former director at Philip Morris, was a prominent CDA member and helped draft the list of members for CDA seats at the general elections in 1998 (Bouma, 2012).

Even when the CDA was in opposition between 1994 and 2002, the industry could still fall back on its connections to tone down the government's tobacco control policy intentions. In these years, advocates and left-wing politicians frequently accused the CDA of protecting tobacco industry interests. During the famous debate in the second chamber on 31 May 2001 about the amendments to the Tobacco Act, Labour Party politician Rob Oudkerk complained at one point, "When I hear the CDA, I hear the droning of the tobacco lobby. That is not a nice sound." At another moment in the debate, Agnes Kant (Socialist Party) remarked about the position of CDA and VVD, which tried to remove advertising and smoking bans from the Tobacco Act, "I must say that when I hear their position and their argumentation, I can still hear the tobacco lobby resounding in this house."

\section{SMOKERS’ Rights Groups}

It was not only direct contacts with the government and politicians that helped the industry ward to off legislation. At times it is more effective to "speak as the smokers" (Smith \& Malone, 2007). The main purpose of 
smokers' right groups was to keep smoking socially acceptable by framing the issue as one of individual rights, not health, and positioning smokers as defenders of freedom (Smith \& Malone, 2007). In 1992 a Dutch national smokers' rights group Stichting Rokers Belangen (SRB) was founded by Philip Morris, with Ton Wurtz as chair and spokesperson. Philip Morris had high expectations of the group. The Dutch SRB formulated its aims in 1998 as follows: "We believe strict smoking bans and laws infringe on our individual rights, impede our society's principle of freedom of choice and reduce tolerance and respect within our society" (Forces USA, 1998). Philip Morris listed as one of the key issues for the Netherlands in 1994, to "continue to support and exploit to a maximum the Smokers' Rights Club. In doing so, develop regional chapters and make the Club a very active group and ally to the industry" (Philip Morris, 1994). According to Philip Morris corporate affairs experts, the SRB was an important media player in 1996, boasting huge numbers of members, and had some success in preventing smoking bans in workplaces and preventing higher tobacco taxes (Philip Morris, 1996a).

It is interesting to contrast this industry-led group with another group that was spontaneously founded on 7 January 1990 as a short-lived protest against the smoking ban that came into force on 1 January of that year. The group Rokers Belangen Vereniging (Smokers' Interest Society) was a colourful mix of Amsterdam-based artists, journalists, and intellectuals. ${ }^{9}$ Its founders wanted to promote the image of the smoker as a "gentle, tolerant, freedom-loving, independent, undogmatic individualist" (Van Gelder, 1990). The group was disbanded soon after it was founded because of incompatible opinions about strategy and lack of interest from smokers.

The Dutch tobacco industry manages to keep the SRB alive to this day, which is remarkable since most smokers' right groups do not survive very long due to lack of support from smokers (Smith \& Malone, 2007). While Philip Morris ceased to lobby against smoking bans in the Netherlands and lost interest in SRB, SSI and VNK continued to financially support SRB. Compared with similar organisations in Europe, the Dutch SRB has been a long-lasting force, more or less a one-man project of its director, Ton Wurtz. Wurtz's most successful initiative was when he, with help from the SSI, founded the small interest group Stichting Red de kleine horecaondernemer (Save the small hospitality entrepreneur) (Baltesen \& Rosenberg, 2009). This foundation of bar owners played a crucial role in masterminding the revolt by pub owners against the smoking ban in 2008, 
which undermined legislation for several years. It was an example of astroturfing - the practice of deliberately staging activities that give the impression of spontaneous grass roots initiatives. The group received support from Wiel Maessen, chair of the Dutch libertarian group Forces, which fights against what it calls the "anti-tobacco industry"-a conspiracy theory in which "Big Pharma" is an omnipotent industry that pulls the strings in the tobacco control network.

\section{The Ministry of Economic Affairs}

For many years representatives from the tobacco sector were natural and undisputed consultation partners for the Ministry of Economic Affairs on tobacco policy issues. The trade ministry was a long-time supporter of the tobacco sector because of the promise of employment and commerce: the industry promoted itself as major investor and job provider. ${ }^{10}$ In 1969 Philip Morris established a company in Eindhoven and in 1981 opened the world's largest and most advanced cigarette production plant in Bergen op Zoom, conveniently close to Vlissingen and RotterdamDutch harbours with facilities for the warehousing of tobacco from overseas. It is also close to Antwerp, the largest port for raw tobacco in mainland Europe. Bergen op Zoom was an economic development zone, which meant that the Ministry of Economic Affairs could offer attractive investment conditions. Through the Investment Account $\mathrm{Act}^{11}$ the government subsidised the new production facility with 6.2 million guilders. ${ }^{12}$ According to one civil servant, "The plant in Bergen op Zoom was constructed with enormous support from the government. The Ministry of Economic Affairs wanted that factory, because this would bring with it a lot of employment for people in the province of Brabant, where unemployment was high. So there was always a sort of understanding between Philip Morris and the trade minister."13 Other tobacco producers (mainly located in the Northern provinces) also advanced the argument of being important to local employment and economy.

The Ministry of Economic Affairs was more powerful than the Ministry of Health. According to one former government official:

If the minister for Economic Affairs wanted something to be done in these days, it just happened. And when the state secretary for Health wanted something, it did not happen. Economic Affairs tried to hold back all aspects of the tobacco dossier. So there was a continuous, big clash regarding 
tobacco policy between the two ministries. There was minister Andriessen. ${ }^{14}$ He was a real powerful trade minister. We wanted to get rid of the principle of self-regulation, but State Secretary for Health Hans Simons could not realise that as long as there was minister Andriessen. Andriessen was just more powerful. So we had to make do with what we had. Hans Simons had to go for the possible, for what was attainable. ${ }^{15}$

For the trade ministry, frequent contacts with the tobacco industry were business as usual. A civil servant from the trade ministry wrote a new year's wish to his contact with the VNK at the beginning of 1992: "There is no doubt that in the new year the branch organisations and Economic Affairs will again have to respond promptly to developments that may cause problems for the tobacco processing and cigar industries. Hopefully we will find each other again in a good cooperative spirit in 1992" (Ministerie van Economische Zaken, 1992).

Concrete threats that Philip Morris might withdraw its economic activities from the Netherlands were frequently voiced in the 1990s. For example, in 1995, when Health Minister Els Borst presented her public health policy intentions, the industry immediately argued that her plans would be devastating to the local and national economy (Vonk, 1995). In 1996 Philip Morris threatened not to expand its factory in Bergen op Zoom if the government's intention to increase tobacco taxation by 50 cents per pack was achieved. ${ }^{16}$ Philip Morris organised an intimidating lobby, part of which was concerned letters to Prime Minister Wim Kok from a wide range of organisations, including labour unions in the tobacco processing sector (Philip Morris, 1996b), the municipality of Bergen op Zoom where the Philip Morris plant was located (Gemeente Bergen op Zoom, 1996), the local chamber of commerce (Hamers \& Vermeulen, 1996), the governor of the province of Overijssel, and the Netherlands Trade Union Confederation (FNV) (Kok, 1996). The industry lobby could not stop the tax increase, but it did manage to have it spread over three years (1997, 1998, 1999), a much better outcome for the industry than the original plan.

Until 1996 it was normal practice that the ministers from Economic Affairs and the Ministry of Health, supported by top civil servants, met in person with the highest-ranking representatives from the industry (directors, CEOs). These were called executive meetings ${ }^{17}$ and took place twice a year. In addition, administrative consultations, ${ }^{18}$ where civil servants discussed and negotiated with the industry about the implementation of current policy and ideas for future policy, were held on a regular basis. Such 
meetings gave the industry a tremendous advantage to organise their lobbying apparatus in case the outcomes of negotiations were not to their liking. Box 8.2 describes how the tobacco industry was able to eliminate the most effective elements from the first Tobacco Act.

Box 8.2 How the industry crushed the first Tobacco Act In 1979 the Interdepartementale Commissie Beperking Tabaksgebruik (Interdepartmental Committee for Reducing Tobacco Use) (ICBT) was set up by the government to draft a Tobacco Act. In December 1980 the ICBT committee organised confidential meetings with representatives from the tobacco sector to solicit their comments on two core elements of the proposed act: tobacco advertising and sales restrictions (Van Londen, 1980). Objections raised by the industry were acknowledged by the state secretary for economic affairs, and in particular objections against limiting tobacco sales to specialty shops. ${ }^{19}$ The industry argued that the reduction of tobacco selling points must occur in a phased manner so that the market could slowly adjust, and argued that the number of specialty shops would be too small to accommodate the national demand for tobacco. After the ICBT report was presented, the government frequently organised meetings of the Werkgroep Afspraken Tabaksbeleid (Working Group on Agreements about Tobacco Policy) (WAT) to ensure that stakeholders from the tobacco industry sector could give further inputs and eventually endorse the Tobacco Act. The full tobacco sector was represented in WAT meetings: from retail organisations, the hospitality sector, tobacco wholesalers, and industry lobby organisations (NVS, SNK, SSI, NSO). The WAT meetings continued until at least 1995 and aimed at "making clear agreements on tobacco advertising, tobacco taxation, selling points, and smoking bans" (Ministerie van Economische Zaken, 1995). They were not open to representatives from health organisations.

In March 1982 the Ministry of Economic Affairs sent a confidential first concept of the Tobacco Act to the Economic Institute for small- and medium-sized enterprises with the request to produce data that demonstrated the economic impact on businesses if the number of tobacco points of sale were drastically reduced (Ministerie van Economische Zaken, 1982b). In October 1982 the Ministry of Economic Affairs sent confidential letters about the government's 
policy intentions regarding the Tobacco Act to WAT members, with an invitation to give feedback and comments (Ministerie van Economische Zaken, 1982a). They also met in person to hear their concerns. At that point the government still wanted to reduce sales to specialised tobacco retailers. In January 1983, in a meeting with the new State Secretary for Health Joop van der Reijden, SSI offered to remove cigarette vending machines from outdoor venues. In February 1983, WAT members met with the state secretaries for health and economic affairs to discuss the matter further, ${ }^{20}$ and SSI and others were allowed to continue to make suggestions for change until the end of that month (SSI, 1983). This was all well in advance of the moment that the proposal for the Tobacco Act was presented to the cabinet for approval (July 1983) and to parliament (end of 1984). The drafting of the proposal was further delayed because the Ministry of Economic Affairs demanded that the text be scrutinised by the Commission Van der Grinten, a new commission that advised on how regulation could be streamlined in such a way as to "reduce legal regulations that hamper the recovery of the economy." "21,22 This gave the industry more time to organise its lobby. Business organisations involved with selling tobacco united and presented a study on the economic consequences of reducing the number of selling venues (Roos, 1985). The study suggested there would be damage to the food retail sector, especially small supermarkets, and argued that many would not survive without the sale of tobacco. This was reason for the Van der Grinten Commission to advise against the idea of restricting tobacco to specialty shops, and this was subsequently removed from the draft act (SSI \& SNK, 1984). The other hot potato, a ban on tobacco advertising, was removed after several rounds of talks in which the industry and the state secretaries for health and economic affairs settled for a continuation of selfregulation by the industry (Evenhuis, 1988; Marres \& Toet, 1987).

The obvious route of industry influence through the trade ministry was disrupted in 1996, when tobacco control became the prime responsibility of the Ministry of Health. This was possible because Minister of Economic Affairs Hans Wijers sided with Minister of Health Els Borst (both D66) after a collision with the industry-when the government's 
new tobacco control policy paper was extensively negotiated by Wijers and Borst in a confidential meeting with a broad representation of the industry sector (Borst-Eilers, 1996). Part of the negotiations was an agreement to set up a new "Platform Prevention of Youth Smoking," financed by the industry (Roelofs, 1996a). This would be a sort of clearing-house of scientific information about effective ways to tackle youth smoking. This platform turned out to be merely window dressing, a strategy to get more leverage over the government. The industry lobbied to prevent majority support in the parliament for Borst's policy intentions, and threatened that they would not finance the youth prevention platform if the major tax increase, announced by Borst soon after her tobacco control policy "nota" was issued, went ahead (Volkskrant, 1996). The industry regarded the tax increase as unjust and threatened to disband their "part of the deal" (Roelofs, 1996b; Van de Mortel \& Roelofs, 1996), claiming that, in return for the industry's cooperation with the tobacco control intentions, the cabinet had promised not to increase tobacco taxes. This led to a quarrel between both ministers and industry lobbyists. On 2 September a large delegation from the industry discussed the disagreement with the two ministers, and the next day SSI issued a press statement with the title "Government breaches agreement" (Van Ronkel, 1996). SSI accused the government of having caused a breach of trust with the tobacco sector. Minister for Economic Affairs Hans Wijers was not amused, since in his eyes a deal with the industry to refrain from tax increases had not been made, and he threatened them: "There is always an alternative, which is regulation." In a snappy letter to the chairman of VNO-NCW he wrote, "Regarding the meeting with the industry I want to repeat what was said in parliament: there were no deals about tobacco taxes to which this cabinet could in any way be committed" (Wijers, 1996). From that moment, Wijers no longer opposed Borst's wishes for effective tobacco control (Van der Bles, 1996) and it became easier for the tobacco control officials at the health ministry to get tobacco control proposals approved in the cabinet, since they only had to try to get the health minister's signature for approval.

In the beginning of 1999, after the second Kok Cabinet was installed, Philip Morris contacted the new Minister of Economic Affairs Annemarie Jorritsma (VVD) to get her support in preventing Health Minister Borst from banning tobacco advertising altogether: "I thank you for your assurance that you will make sure that the interests of the concerned industries 
will be optimally protected when the European guideline concerning tobacco adverting will be implemented" (Schipper, 1999b). In June Jorritsma and Borst had an executive meeting with tobacco industry CEOs to discuss the industry's wish to resume "constructive dialogue" with the government (Schipper, 1999a). According to the industry, the ministers had promised to reinstall "regular executive level meetings," but two years later this had not yet occurred (SSI, 2001). In the meantime, employers organisation VNO-NCW complained to the minister of economic affairs that it was not doing enough to restrain Borst's plans for a revision of the Tobacco Act, which had just been sent for approval to parliament: "We find it difficult to understand that this kind of measures can be proposed with the support of the ministry of Economic Affairs, and cannot be stopped by Economic Affairs" (Blankert, 1999). Jorritsma wrote several "blue letters" (direct confidential letters between ministers) to Borst to try to restrain her, without success (Bouma, 2001, p. 94). When Borst asked the state attorney to study the possibility of suing the industry for the public health damage it had incurred, inspired by major court cases in the United States which had led to the 1998 Master Settlement Agreement, ${ }^{23}$ the hostile attitude of the health minister and her staff was of great concern to the industry (discussed in more detail later in this chapter).

Despite tobacco control now being firmly in the hands of the Ministry of Health, and regular top-level meetings with the health minister had been terminated, the industry still tried to influence the ministry's tobacco control policy through the Ministry of Economic Affairs. Email exchanges between the Ministry of Economic Affairs and the Ministry of Health, found in the Truth Tobacco Industry Documents database, ${ }^{24}$ reveal that the industry continued to maintain contact with officials from the trade ministry. An example of this, presented in Box 8.3, describes how the industry used the Ministry of Economic Affairs to extract information from the Ministry of Health about the Dutch position regarding the European Commission (EC) proposal for a council Recommendation on smoke-free environments in that year. The example illustrates how persistent and intensive the industry lobby at times was, even regarding what was initially thought to be a relatively unimportant matter such as a non-binding EU Recommendation. The industry was more up to date on the position of the various EU countries about upcoming legislation from Brussels than tobacco control advocates and politicians were (Algemene Rekenkamer, 2012). 


\section{Box 8.3 How the industry influenced the Dutch position on an EU Recommendation}

The Recommendation on smoke-free environments (2009/ C296/02) included the advice to support national smoking bans with specific additional measures. One of these was health warnings on cigarette packs. Much to the dismay of the industry, France proposed to turn this into a recommendation to consider plain packaging, and this led to a massive industry lobby both in the European arena and directed at national governments. The Netherlands was seen as crucial for a blocking minority, since the industry knew that Health Minister Klink (2007-2010) objected to graphic health warnings on cigarette packs, and would probably also not endorse the idea of plain packaging. In the Netherlands, civil servants at the Ministry of Economic Affairs, as well as at the Ministry of Health, and the health ministry's permanent representative in Brussels were approached by telephone and email, and letters were sent directly to Health Minister Klink, reminding him of his former statements about health warnings. Industry lobbyists asked Klink to object in the European Council of Health Ministers to the plain packaging advice. In reply to an email in which a lobbyist from Philip Morris pointed out industry concerns, a senior policy officer from the trade ministry replied, "Thank you for your mail. I appreciate very much that I am being informed about such signals from the business community. I will discuss this at short notice with my colleague at the Health Ministry. I'll give you an update afterwards" (Ministerie van Economische Zaken, 2009b). The official then did discuss the industry's concerns with his colleague at the Health Ministry, but from the emails it is clear that the official was uncertain if the issue was important enough for the trade ministry to act, since it was not immediately clear whether employment and cigarette production would be harmed (Ministerie van Economische Zaken, 2009a). The industry then contacted the state secretary for economic affairs directly, bypassing the civil servant: "I would appreciate it very much if you could have the matter looked into and if possibly take action against including plain packs in the proposed recommendation" (Ministerie van Economische Zaken, 2009c). In October the pressure was increased through a series of letters from industry stakeholders (SSI, VNK, VNO-NCW, PVT) directed at ministers and 
state secretaries for health, economic affairs, and finance, all urging the government to remove references to plain packs from the EU Recommendation. Philip Morris mobilised its contacts in parliament, resulting in an MP from the VVD asking parliamentary questions. ${ }^{25}$

Industry concerns increased when the plain packaging text was approved by the Working Party in the Public Health Commission (which prepares texts for the EU Health Council), despite objections by a minority of countries including the Netherlands. Next the proposal was to be discussed in the Committee of Permanent Representatives (COREPER), the highest preparatory body for meetings of the European Council of Ministers. The Dutch trade ministry considered taking extra steps to use its own network to influence EU countries which were neutral or still positive about plain packs: "Currently the Ministry of Economic Affairs examines (other) possibilities to change the minds of proponents of the Recommendation, for example through our economic diplomats network or by exploiting the argument of intellectual property" (Ministerie van Economische Zaken, 2009c).

At the COREPER meeting there was an intense debate between member states for or against an advice on plain packaging, with the Netherlands still against. Because this threatened the survival of the Recommendation, COREPER finally reached a compromise, which was to remove the advice to member states to implement plain packaging-a victory for the industry lobby. It is difficult to determine how influential the industry lobby was in achieving the end result, but it is reasonable to assume that, without its insistent pressure, countries such as the Netherlands might have given in to countries that were in favour.

Insistent industry pressure is very difficult for government officials to ignore. The example in Box 8.3 illustrates how the industry engages simultaneously at different levels: bureaucratic (targeting civil servants), political (targeting MPs), and governmental (targeting ministers); and that it does so in a coordinated fashion. It is unclear as to what extent this has changed, despite recent efforts from the government to improve the implementation of Article 5.3 FCTC, which aims to prevent industry interference with tobacco control policymaking (discussed in Chap. 6). 
Around 2010, at the end of the ministership of Ab Klink, VNO-NCW made a stab at returning to the days when the Ministry of Economic Affairs had formal shared responsibility over tobacco control. It wrote to the ministry: "we would like to offer our help to increase the effectiveness of your department on several [tobacco] issues. ... VNO-NCW will take the initiative for a further meeting to prepare for strengthening of the role of your ministry" (VNK, NVS, SSI, \& Philip Morris Benelux, 2010). In December 2010, soon after Health Minister Schippers entered office, VNO-NCW presented a memo by SSI in which it pleaded for a "strong and balanced role" for the trade ministry in the future formation of tobacco control policy, and asked that the trade minister once again cosign new tobacco, alcohol, and food legislation and be consulted by other ministries on these topics (VNO-NCW, 2011b). VNO-NCW's director asked its high-level contact at the trade ministry to discuss this with "Maxim" [Minister for Economic Affairs Maxime Verhagen] and pointed out that the alcohol and tobacco industry had suffered from the "onesidedness of policy and the failure to understand their position. Would it not become time to restore the influence of the trade ministry to its old splendour?" (VNO-NCW, 2011a). Despite these attempts, Economic Affairs was content that the Ministry of Health handle the difficult tobacco policy dossier, as long as Economic Affairs was allowed to play a role from the side-line- that is, as long as it was consulted by the Ministry of Health about the impact of tobacco policy on the business sector through interdepartmental consultations.

\section{Vanished Employability in the Tobacco Sector}

While employment arguments might have been valid in previous decades, they have become hollow in recent years. Cigarette manufacturing is highly mechanised in the Netherlands, contributing little to the number of jobs. Throughout the twentieth century employment in the Dutch tobacco production sector became less and less important (Fig. 8.1). BAT produced cigarettes in Zevenaar until 2008, when the factory was closed and production moved to Eastern Europe. The Philip Morris facility was as good as closed in 2014, resulting in more than 1200 job losses. After the closing of this one factory, a civil servant at the Ministry of Economic Affairs confirmed that the importance of tobacco employment in the Netherlands had become "actually negligible" (Rijsterborgh, 2017).

With the disappearance of the huge production and export volumes of manufactured cigarettes of the past, the industry lost one of its leverages: 


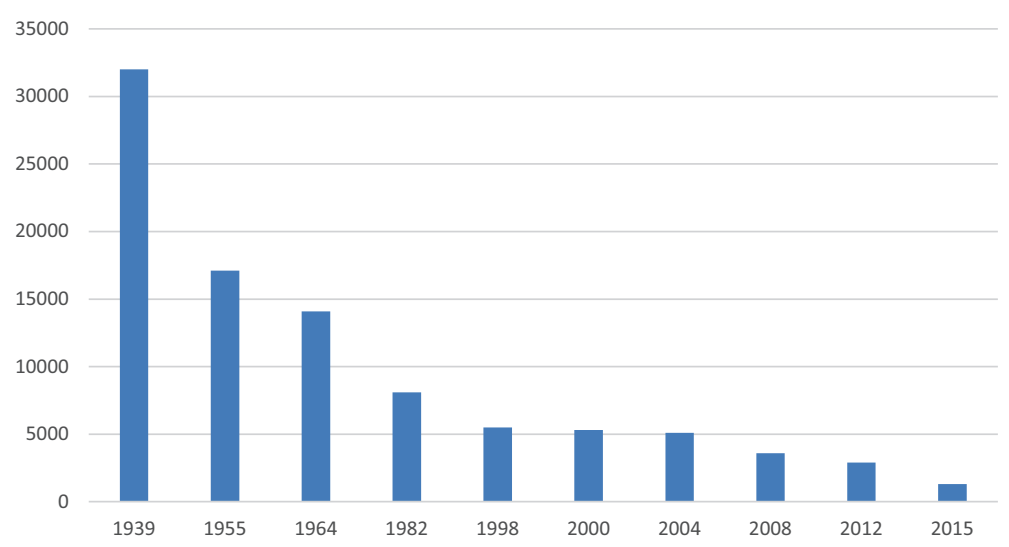

Fig. 8.1 Number of workers employed in tobacco production in the Netherlands since 1939. Sources: Van Proosdij (1957, p. 186) (data 1955), (Mantel \& de Wolf, 1983) (data 1939, 1964, 1982), (De Steur) (data 1998), (Rijsterborgh, 2017) (data 2000, 2004, 2008, 2012, 2015, based on Statistics Netherlands StatLine)

its contribution to the national trade balance. In the mid-1980s the contribution of the Dutch tobacco industry to the national trade balance was still greater in the Netherlands than in other EU countries (Voorlichtingsbureau Sigaretten en Shag, 1986), but nowadays this is modest. Macro-economic considerations in relation to the tobacco manufacturing sector have therefore become unimportant to the Ministry of Economic Affairs. However, other arguments, such as threats to intellectual property as in the case of plain packaging, may still be used to get the ministry on its side.

\section{Agreements with the Ministry of Finance}

The tobacco sector has been cherished by the Ministry of Finance for many years because of the secure contribution of tobacco tax to the national state income. At the end of the 1970s, Philip Morris was pleased with the protection it enjoyed: "The strong influence of the Ministry of Finance and the complexity of the legislative process in Holland have aided in forestalling legislation to date" (Philip Morris, 1979). One former civil servant characterised the relationship that the government had with tobacco during the 1980s as "primarily a matter dealt with by the 
finance ministry. The Ministry of Health had to keep its mouth shut. If there is no tobacco control policy, all the better, because the incoming flow of money must not be disturbed." ${ }^{26} \mathrm{He}$ continued:

The cheapest patient is a dead patient. That was what the industry told Finance and Economic Affairs, I am sure of that. ... It is better for the state to do nothing. This will give you more revenues from tax. Smokers live shorter so we will have fewer costs. So for the state it is cheaper to do nothing against smoking. I have heard such points of view often when we had interdepartmental meetings. So it was always David against Goliath [the Ministry of Health against the other ministerial departments] in these early days.

When we look at the proportion of state income that comes from tobacco, we see a remarkably stable trend: tobacco tax revenues provide a steady state income, which has been between $0.5 \%$ and $1 \%$ of the total state income since 1995 (Fig. 8.2).

Despite the weak price elasticity, major price increases through substantial and frequent tobacco tax hikes are widely considered the most effective tobacco policy measure (Jha \& Chaloupka, 2000; Nagelhout, Levy,

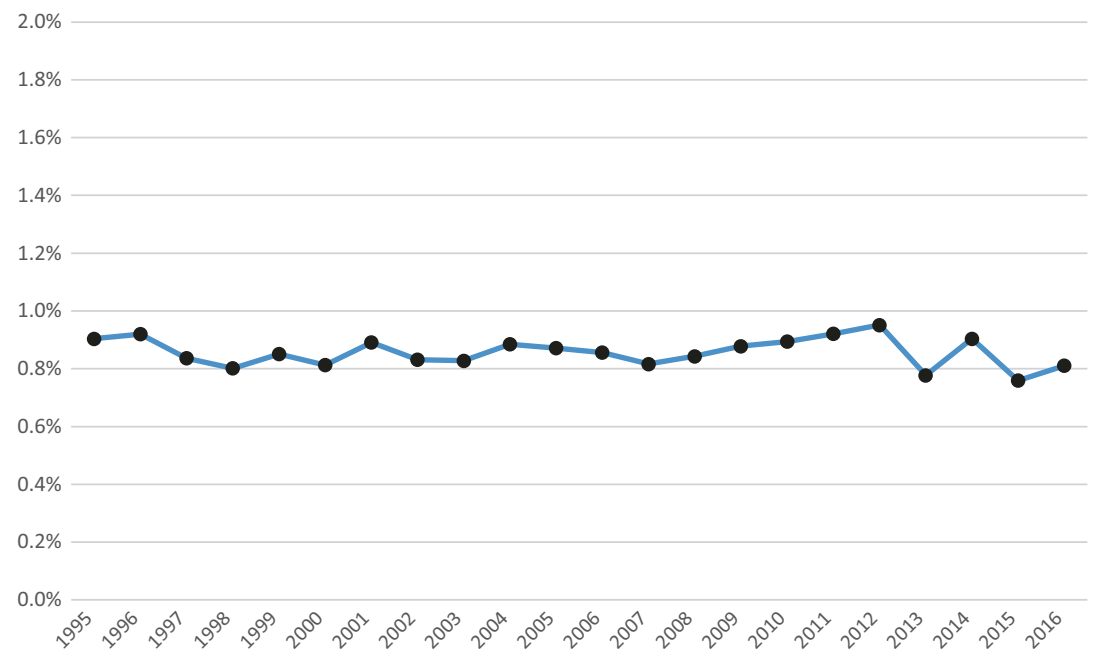

Fig. 8.2 State revenues from tobacco taxation (excl. VAT) as a proportion of the total state income per year. Source: CBS (Statistics Netherlands): http://statline. cbs.nl/Statweb/?LA=en 
et al., 2012). However, the levying of excise duties originates from the Wet of de Accijns (Excise Duty Act) administered by the Ministry of Finance. ${ }^{27}$ This means that the single most effective way to address the smoking problem is not under the direct control of the Ministry of Health-and the act does not mention health as a reason for tobacco tax increases. In 2014 representatives of the Tax and Customs Administration confirmed that the act's primary purpose is to raise revenue for the government (Loubeau, 2014). The positive effect of tobacco taxation on public health is regarded by most Dutch politicians as "a politically interesting sideeffect" (Van Baal, Brouwer, Hoogenveen, \& Feenstra, 2007). The Ministry of Health has to negotiate with the Ministry of Finance if it wants to use tobacco taxation as a way to protect health. This is what an ex-civil servant from the Health Ministry had to say: "Very often we tried to push for tax increases. But this was only possible when they [the Finance ministry] deemed that the time was right. I have always experienced this as very troublesome. A dialogue with the deaf." 28

Tobacco manufacturers meet regularly with officials at the Ministry of Finance for "tobacco deliberations" (Ministerie van Financiën, 2011, p. 6). Because of the divergent interests of the various manufacturers regarding taxation, there are also separate contacts between individual businesses and the ministry. ${ }^{29}$ According to one former Dutch industrial lobbyist, "The tobacco industry has much more knowledge about how taxation works. It is all very technical and quite a few people at the Ministry of Finance retired. So concerning technical knowledge, they had an information shortage. ... The industry is very capable of showing how specific types of taxation [e.g., gradual instead of abrupt] will be more effective for the treasury." 30

For long, the Ministry of Finance has been receptive to suggestions by the industry on how tax increases might best be realised, as long as the end result is the same for the treasury (Philip Morris, 1989; SSI, 1991; VNK, 1991). Indeed, changes in taxation initiated by the government usually occur after consultation with the industry. ${ }^{31}$ At irregular intervals, the government adjusts the taxation level if it temporarily needs to fill holes in the state budget. This requires changes to the taxation law, and parliamentary approval. This happened in 1991 (three gradual increases in 1992 and 1993), 1996 (three small increases from 1997 to 1999), 2001, 2004, 2006, 2008, 2010, 2011, 2013, and 2015. With the exception of 2004, 2008 , and $2013,{ }^{32}$ the tax increases were small and intentionally imposed in a gradual manner, to minimise their effect on tobacco consumption. 
The fact that tax increases are usually gradual rather than abrupt is a major success for the industry. For example, in 1991, at the height of national austerity measures, the government needed 500 million guilders extra income. The SSI made extensive preparations and presented a report with a proposal to realise the needed revenue for the state in an industryfriendly manner. The proposal was presented by industry representatives to the minister for finance (Klijn \& Toet, 1991) and extensively discussed in parliament. ${ }^{33}$ Although the tax was higher than the industry wanted, most of their other recommendations were adopted and tax levels were increased gradually (in three six-months intervals) to minimise behavioural effects that would undermine the net effect on the coffers or reduce industry profits. ${ }^{34}$

The industry had some other notable victories with the Ministry of Finance. Because the consumption of roll-your-own tobacco products increased dramatically between 1975 and 1985, while the consumption of the much more expensive manufactured cigarettes went down (Mindell \& Whynes, 2000), cigarette manufacturers complained that the economic crisis affected them disproportionally, employment in their sector was threatened, and they needed a greater profit-earning capacity in order to survive. After lobbying from the cigarette manufacturers, a motion by VVD parliamentarian Jos van Rey supported by the Ministry for Economic Affairs (Ministerie van Economische Zaken, 1984) resulted in a decision by the Minister of Finance to reduce the tax on manufactured tobacco in 1984 (from $74 \%$ to $72 \%$ ). ${ }^{35}$ This enabled the industry to increase the price of a pack of cigarettes by 15 cents without the risk of losing customers. The industry was so pleased with this result that it organised an informal diner party at the high-class Hotel Des Indes in The Hague, inviting industry business organisations who benefited from the price increase and all involved officials from the Ministry of Economic Affairs and Ministry of Finance, including the state secretaries who helped to make it possible (SSI, 1984).

Tax increases are thus carefully fine-tuned after consultation with the tobacco sector. The industry frequently takes advantage of tax increases by increasing their wholesale price, while minimising the effect of tax increases on sale volumes. For example, the effect of the 2006 tax increase on smoking behaviour was neutralised by the industry, which simply reduced the number of cigarettes in a standard pack from 20 to 19. On other occasions the industry adjusted the volume of tobacco in roll-your-own pouches downward, to camouflage tax increases: in 2009 the weight of tobacco in 
roll-your-own packs was reduced from 50 grammes to 45 grammes. In 2011 it was 42.5 grammes and in the next year it was further reduced to 40 grammes of tobacco. Parliamentarians have repeatedly asked for a system where tax level is directly related either to the weight of tobacco, so that cigarettes and roll-your-own tobacco are equally taxed, or to the harmfulness of the product, so that products with higher tar and nicotine levels become more expensive. ${ }^{36}$

Dutch industry lobbyists not only put their stamp on national tax policy, but at times also use their contacts at the Ministry of Finance to influence European policy. For example in 1991, when the EU decided on a minimum tariff of $57 \%$ for tobacco products (Philip Morris, 1989), the Dutch Minister of Finance Wim Kok, who was chair of Ecofin (the Council of Ministers of Economic Affairs and Finance of all EU countries), was heavily lobbied on this issue by Philip Morris, which presented doomsday scenarios of job losses and negative effects on national trade balances (Philip Morris, 1989). The Minister of Economic Affairs asked Kok if he, in his capacity as chairman, could give ample speaking time and opportunity to the UK delegation to question the $57 \%$ tax ruling during the Ecofin meeting (Philip Morris, 1989). Afterwards the industry thanked the officials from the Ministry of Finance "for the efforts by the minister, the state secretary and yourself to bend the decision in, for the Dutch business community, a more acceptable direction" (Philip Morris, 1989). Another example of industry lobbying occurred between September 2008 and April 2009, when lobbyists visited the finance ministry nine times and also had a meeting with the State Secretary for Finance Jan Kees de Jager. The topic of the talks was the EC's wish to abandon minimum taxation levels for cigarettes (Algemene Rekenkamer, 2012). At first the government was in favour of the EC proposal, but after industry's lobbying efforts, it changed its position to neutral.

\section{Targeting the Ministry of Health}

Civil servants responsible for tobacco control policy in the Ministry of Health were main targets of tobacco industry lobbyists. In the 1980s and 1990s, there were only two civil servants dealing with tobacco control, and they had to divide their attention with other issues such as alcohol control and drugs. One government official described the government's relationship with the industry during these years: "There are frequent meetings between government and tobacco industry because of parallel 
interests ... the government requests the industry to do certain activities (for example, self-regulation of advertising) and the same happens the other way around. The activities of the tobacco industry are important for the success of governmental policy regarding smoking" (Wever, 1988). It was normal practice that ideas for new tobacco legislation were discussed with sparring partners from the industrial sector. This suggests it was very much an insider game. Only when proposals had reached a certain level of incontrovertibility were broader consultation meetings organised. Symptomatic of the type of relationship was the fact that when two leading civil servants who were responsible for tobacco policy left the Ministry of Health in 1992, industry representatives were present at their farewell reception. ${ }^{37}$

The government continued to allow self-regulation of tobacco advertising by the industry well into the 1990s. As government officials needed to have contact with the industry to discuss details of the advertising code of conduct, this developed into a habit of seeing and meeting each other on a regular basis, which was a great advantage for the industry. At such meetings all aspects of tobacco control could be raised, and it became normal practice that proposals for new tobacco policy made by the Ministry of Health were sent directly, or through the Ministry of Economic Affairs, to the industry for scrutiny and comment, before they were sent to parliament (NVS, VNK, \& SSI, 1990). Small steps in regulation and restrictions, especially regarding the many versions of the self-imposed code of conduct regarding tobacco advertising, were discussed endlessly with the industry, which treated these talks as if they were negotiations, while the government regarded them more as consultations. The industry presented their contributions as "concessions" and "giving in" to wishes of the government (Marres \& Toet, 1987). In 1992 the code had to be renewed, and the Health Minister, Hans Simons, wanted it substantially improved, with fewer loopholes for the industry and termination of advertisements promoting positive images of smokers. This involved many meetings with the industry between 1992 and 1994 about the exact content of the new code. The industry's full support from the trade ministry, gave it a strong position during these talks, evidenced by the fact that they could get away with refusing to end tobacco advertisements. They continued advertising at the important international Formula 1 races in Zandvoort and at TT motorcycle events in Assen, a trade-off for the relatively unimportant termination of tobacco promotion through billboards at motorways. ${ }^{38}$ 
During the 1990s civil servants in the Ministry of Health became increasingly agitated by the arrogant attitude of the industry: "There is very little progress in the talks with the tobacco industry about reducing advertising through self-regulation. We do everything in our power to get concrete results, but the tobacco industry manages to sabotage everything, both regarding the content and regarding the process" (Wever, 1992). Another civil servant complained, "The tobacco advertising dossier has become rather extensive. The lobby by the (inter)national businesses (worldwide tobacco manufacturers, VNO-NCW, European employers, advertising agencies, publishers, media exploiters etc.) is immense" (Engelsman, 1992).

When Hans Simons was state secretary for health in the Lubbers III cabinet (1989-1994) the relationship with industry representatives began to stiffen, because Simons wished to intensify tobacco control. In 1994 he sent a summary of the outcomes of negotiations with the industry about the new advertising code to parliament, and received a prompt letter from SSI. The industry was outraged by what they saw as false representation of their intentions: "The industry is seriously disappointed and feels unjustly treated during the contacts with your department. This is all the more troublesome since this has happened already several times in the recent past" (Toet, 1994).

\section{Industry Contacts During the Ministership of Els Borst}

One year after Health Minister Borst (D66) began preparations to revise the Tobacco Act in 1994, she received an unambiguous signal from Alexander Rinnooy Kan, chairman of employee organisation VNO-NCW, that she was on a collision course with VNO-NCW (Rinnooy-Kan, 1995a, $1995 \mathrm{~b}$ ), and she was warned not to proceed with her intended plans. He wrote that VNO-NCW would not take it lightly if she dismissed selfregulation ("an agreement is an agreement") or if the advertising code was not continued for the full period of five years: "It must be clear to you that we do not accept a more paternalistic government."

The industry was intensely involved in the process of drafting the ministry's tobacco control policy document, which contained detailed proposals for a revised Tobacco Act, and industry spokesmen even made concrete suggestions for text changes (Van de Mortel, 1996) — the health sector was not consulted. Only after the text had been leaked to the press 
was STIVORO able to join in (Boudewijn De Blij, 1996a). In a letter to parliament, STIVORO's director Boudewijn de Blij noted, "It strikes me that the industry has been involved in every phase of the realisation. I expect STIVORO to be involved in such important decision making processes as well" (Boudewijn De Blij, 1996b). Parliamentarian Rob Oudkerk (PvdA) responded, "The tobacco industry relies on excellent lobbyists. They have accomplished a lot during 14 meetings with the cabinet, without any involvement from parliament. Cabinet and parliament have only debated about [the bill] twice" (Bruinsma, 1996).

As was discussed previously in Chap. 2 of this book, in 1996 routine meetings between the industry and the government to discuss tobacco policy were abandoned and the Ministry of Economic Affairs stepped back in favour of a more dominant role from the Ministry of Health, so the industry sought new ways to improve and strengthen communication with the tobacco policy officers at the Ministry of Health. They were not very successful. The relationship between industry representatives and the Ministry of Health at the time could best be characterised as distant and reserved, certainly not warm and welcoming.

In 1997 the ministry agreed to have "broad regular meetings" to which "other interested parties would also be invited, so that all aspects of comprehensive tobacco control policy could be discussed" (Van Hoogstraten, 1997a). This implied that not only would the tobacco industry be invited, as had been previous practice, but also representatives from the health sector. After the cabinet made its tobacco control policy intentions public, the Ministry of Health organised a broad consultation session in September 1997 (Van Hoogstraten, 1997b). The health sector including STIVORO, the Heart Foundation, Cancer Society, Medical Alliance Against Smoking, Clean Air Netherlands (CAN) and the Gemeentelijke Gezondheidsdienst (Association of Community Health Services) (GGD) was to be heard in the morning. Representations from civil society such as VNO-NCW, labour unions, NOC-NSF (the national sports federation), consumer organisations, the advertising sector, and the hospitality sector could present their arguments in the afternoon, followed by the tobacco industry sector, represented by lobbyists from LBT, SSI, VNK, NVS, and NSO. Soon afterwards Health Minister Borst received a letter from SSI, complaining that the Ministry of Health did not seem to take industry arguments seriously: "During these talks we brought a great number of concerns to 
the table. It is now clear that in no way whatsoever did you include any of our concerns in your policy" (Roelofs, 1998). VNO-NCW sent a critical letter to Borst demanding that "the wish list of this cabinet can be and must become considerably shorter" (Blankert, 1997). From these and other letters at the end of the 1990s it is clear that the industry had completely lost its inside grip on tobacco control policy and fell back on intimidation and external pressure.

For many years the tobacco team at the Ministry of Health was understaffed. Until 2000, only two public servants dealt with tobacco. They were not full-time dedicated staff, since they also had to deal with alcohol. In 1998, Minister Borst was asked in parliament why it took her so long to implement the tobacco control initiatives that she had presented two years earlier. She explained that the new tobacco control policy "contains in total more than 50 initiatives, intentions, projects and actions. ... All this work, in addition to the complete alcohol control policy, has to be done by just a few workers at my department." ${ }^{39}$ Her predecessor, State Secretary Hans Simons, had also complained that he was so understaffed that negotiations with the industry about the advertising code of conduct were difficult and took too much time. ${ }^{40}$ Sometime around 2000 the tobacco team was reinforced with three dedicated civil servants and a liaison officer from STIVORO to help adopt and implement the new Tobacco Act. Inspired and protected by Minister Borst, these officials were dedicated tobacco control advocates. The team worked closely with health organisations and kept contact with tobacco industry spokespersons to a minimum, but this did not mean that contact was rare. Officials and industry representatives continued to meet frequently to discuss technical aspects of regulation (such as specific allowances regarding advertising at points of sale), and industry representatives were given the opportunity to present their concerns and problems to the civil servants and sometimes to the director-general. A tobacco control officer said,

You just wanted to allow all concerned parties to have their say. Did we write the correct text, are there any other ideas? Yes, you cannot write a product regulation proposal without ever having talked about it with the industry. ... It was common practice. ... I believe it is appropriate that we do it like that. This is sort of the consensus model that we have in the Netherlands: polderen and deliberating until we have a good outcome. ${ }^{41}$ 
VNO-NCW continued, unsuccessfully, to lobby for periodic regular meetings with the Ministry of Health (Schraven, 2001b).

\section{Minister Borst Turns Her Back on the Tobacco Industry}

In May 2000 the relationship between the industry and the Ministry of Health reached a dramatic low. Borst, in an interview with morning newspaper De Telegraaf, announced "rigorous measures" against tobacco and declared there was no future for tobacco in the Netherlands. The industry reacted furiously. Immediately the next day they sent an angry letter to her, with carbon copies to the ministers for social, economic, and financial affairs, and to parliament (Roelofs, 2000a), and a separate letter to prime minister Kok (Roelofs, 2000b). They blamed Borst for not talking with the industry: "This is not the first time that you have unilaterally launched proposals and ideas in public without first engaging in a constructive dialogue with us.... Your approach to repeatedly confront the tobacco industry through the media with new measures and unfounded accusations is unacceptable to us." They demanded that the prime minister call Borst to account for "the way she chooses to deal with the tobacco and related sectors ... letters are not replied to, appointments are not kept and requests for executive meetings are ignored. ... We assume that you are willing to call upon your colleague from the Ministry of Health to normalise relationships with our sector."

A few weeks later, a meeting was indeed organised between VNO-NCW and Borst, accompanied by her top-level civil servants (Schraven, 2001a). They reached a compromise: there would be a dialogue between the Ministry of Health and the industry under independent chairmanship. Since this did not happen, VNO-NCW brought the matter up again a year later and proposed the possibility of an executive-level meeting once or twice per year between the industry and the ministers for health and for economic affairs (Schraven, 2001a). In addition they proposed regular tobacco policy expert meetings, open to both industry experts and experts from all involved societal organisations, ranging from STIVORO to smokers' right groups. However, Borst, who wanted to finalise her revision of the Tobacco Act before the end of her time in office, continued to hold off contact with the industry sector, despite many letters from the industry complaining that they were not heard. She allowed her civil servants to push the bill forward with limited opportunities for the industry to be consulted about the timing of its implementation (Horeca Nederland, 2002; Kalis, 2002). 


\section{Health Ministers Keep the Industry at a Distance}

The SSI approached Borst's successor, Eduard Bomhoff, soon after he started work as the new minister for health. Bomhoff, a university professor in economics, had been a member of the Labour Party for many years, but was asked by the populist Lijst Pim Fortuyn (Pim Fortuyn List) (LPF) to take up the position of health minister in the first Balkenende Cabinet. SSI wrote him a long letter complaining about the "unacceptable way the Ministry of Health currently does not give meaning to a decent dialogue with the concerned industry sectors," demanding a resumption of "constructive dialogue" and requesting that the implementation of the Tobacco Act be put on hold (Monkhorst, 2002; SSI, 2002). Bomhoff replied in unmistakable terms that he wanted no personal contact with the industry, and was not willing to consider a respite in the implementation process (Bonhoff, 2002).

Bomhoff was minister for a very short period in 2002. Because of a fight between him and the Minister for Economic Affairs Herman Heinsbroek (LPF), the cabinet resigned. When his tasks were temporarily taken over by State Secretary Clémence Ross-van Dorp (CDA), VNO-NCW recognised an opportunity to bring the idea of regular executive meetings to her attention (Schraven, 2003a). Instead of granting the request, the ministry sent a short questionnaire to a large number of societal and business organisations with a stake in tobacco policy, asking them whether they were interested in being part of regular broad meetings about tobacco control policy (Kalis, 2003). When it became clear that these had also been sent to health organisations, the industry stepped down, not liking the prospect of having meetings with the ministry in the presence of tobacco control advocates. The ministry received replies from 26 of 67 organisations, insufficient for regular meetings (Hoogervorst, 2003b), and instead decided to continue the habit of granting meetings with individual stakeholders as circumstances required.

In the meantime, the industry and civil servants at the Ministry of Health had various meetings to discuss the ramifications of the transposition of the EU Tobacco Product Directive (TPD-1). The most difficult issue was the requirement that manufacturers submit lists of all additives used in the manufacture of their products, specifically at the level of each brand. The industry was not prepared to do this without a fight, claiming 
that the requirement infringed on company secrets. They tried to offer alternative formats that would entail a far smaller level of detail. State secretary Clémence Ross did not give in to their pressure, and after numerous letters and fruitless meetings between industry and government officials she published the regulation in the Bulletin of Acts and Decrees in April 2003.

Not only ministers Borst and Bomhoff but also their successor Hans Hoogervorst (health minister from 2003 to 2007) resented industry lobbyists. Hoogervorst made it clear that he had no intention of reinstalling the executive meetings (Hoogervorst, 2003b) and was not prepared to discuss the decision to make public the ingredients of cigarette brands (Hoogervorst, 2003a). A few weeks later the industry summoned the Dutch state to argue the ingredients matter in court.

Just after Hoogervorst took office, the Framework Convention on Tobacco Control (FCTC) treaty was signed by the Netherlands. This meant that the government was expected to refrain from interactions with the tobacco industry unless it was "strictly necessary to enable them to effectively regulate tobacco industry and tobacco products." ${ }^{42}$ While Hoogervorst was minister, VNO-NCW was frustrated that regular meetings were not reinstated (Schraven, 2003b). Hoogervorst's policy regarding interaction with the industry was in line with the FCTC requirement: he only allowed contact about technical issues of implementation of tobacco regulation, of which he gave this example: "The government does not talk with the industry about whether there must be graphic health warnings on tobacco packages, but the government can initiate contact with the industry about practical matters such as the transition period that is necessary to adjust the packs." 43 Throughout his term in office Hoogervorst refused cooperation or meetings with the industry about general policy, explicitly referring to the FCTC (Dortland, 2005; Hoogervorst, 2006a, 2006b). However, the Ministry of Health allowed industry representatives to have bilateral contact with civil servants to discuss "concrete policy matters" (VWS, 2003). It is clear from the email correspondence published in the Truth Tobacco Industry Documents database $^{44}$ that the bureaucrats from the ministry did this reluctantly until around 2008 , often using the formal " $u$ " to address the recipient in emails, keeping the language aloof and business-like, while the industry used the informal " $j e$ " and was more direct and, at times, intrusive and pushy. 


\section{The Ministry of Health Resumes Contact with the Industry}

In contrast to the three previous ministers, health ministers Ab Klink (2007-2010) and Edith Schippers (2010-2012) did not regard contact with the industry as inherently problematic. At first the ministry told the industry that the policy of the previous ministers, that there could be no collaboration between government and the tobacco sector regarding policy, would be continued (De Goeij, 2006), but this changed when Klink, after four months in office, granted a personal meeting with industry CEOs (Smid, 2007), followed by an "exceptionally constructive" (in SSI/ VNK's words) meeting with SSI and VNK (SSI \& VNK, 2007). Further meetings were planned to discuss industry ideas about such things as youth smoking prevention and new safer cigarettes (Klink, 2007). Minister Klink set the example and the norm for how government officials should communicate with the industry, and the number of contacts increased and emails between officials and industry representatives had a friendlier tone. Civil Servants fell back on the familiar habit of involving and consulting the sector. Symptomatic of the desire not to step on industrial toes was a reassuring response from one of Klink's tobacco control officers to a letter in which SSI expressed its concerns about the drafting of the guidelines to WHO Article 5.3, which could lead to full exclusion of the industry from the policymaking process: "First of all, I want to stress that it concerns non-binding guidelines. ... Secondly, it is certainly not a matter of excluding the industry" (De Jager, 2008).

In March 2009, halfway through Klink's ministership, Director-General Hans de Goeij, who had a solid track record in tobacco control, was replaced by an economist who had less affinity with public health. The new Director-General for Health Paul Huijts, a former employee of the Ministry of Economic Affairs, set out to restore the dialogue with the industry that had gone astray under previous ministers. On 24 August 2009 , after a meeting with the industry, Huijts looked back on "a useful and positive meeting, in which mutual interests and differences were well covered. ... Future meetings ... will have to contribute to mutual information exchange and the building up of mutual trust" (Huijts, 2009). Soon afterwards, the industry confirmed that it shared with the ministry the wish to come to a better understanding and was grateful that the ministry was again "open to any contacts, interventions, signals or questions" (NVK, NVS, SSI, \& Philip Morris Benelux, 2010). 
In 2009 Ministry of Health officials accepted an invitation from VNK to attend a "company day" (VNK \& Ministry of Health, 2009). In the past, the industry had organised yearly small conferences around a specific theme, sometimes combined with a visit to a company or factory, for small groups of government officials. These meetings had been abandoned during the previous cabinets, but were reinstated under Huijts' leadership. The meeting took place in September 2009 and was attended by officials from three ministries (finance, economic affairs, and health) (VNK \& Ministry of Health, 2009). In 2011 officials from the ministries of health, finance, and economic affairs visited a tobacco factory (VNK, 2011).

The responsive attitude towards the tobacco industry continued when Edith Schippers (VVD) became minister for health in October 2010. In reply to a congratulatory letter, Schippers confirmed to SSI and VNK, "I appreciate the intention to invest more in the coming time in an open and constructive exchange of thoughts about different international topics" (Schippers, 2010). The government's "generous" interpretation of the FCTC commitments, and in particular Article 5.3, lasted until 2016, when it felt obliged by a court case initiated by the Youth Smoking Prevention Foundation to rethink its policy regarding Article 5.3 and to settle for an implementation more in line with the spirit of the FCTC (discussed in Chap. 6).

\section{CONCLUSION}

In the first decades of tobacco control policymaking, the situation in the Netherlands was similar to that of the United Kingdom in the 1980s, where the tobacco industry survived, despite health concerns, under the protection of a "smoke ring" of tobacco-friendly individuals and organisations (Taylor, 1984). Such "iron triangles" were close-tied networks of lobbyists, advisory bodies, parliamentarians, and government officials who shared specific values and political ideology in line with industry arguments. ${ }^{45}$ The industry felt protected through gentlemanly networks, able to lobby through direct contacts with ministers.

In the mid-1970s the iron triangle was challenged in the publication of the Health Council report Measures to Reduce Smoking. From then onwards, the industry had to defend its interests more proactively, to prevent the balance of power from shifting in an undesirable direction. This chapter has presented many examples of how the Dutch tobacco 
industry lobbied. Continued conflict with the industrial sector over regulation versus self-regulation was the main reason why it took until 2002 to revise the Tobacco Act. Until the mid-1990s the industry lobbied through direct contacts with ministers, while the health organisations had to rely on an outside lobby, most of the time relying on politicians who could not gather majorities in parliament. Well-known lobbyists who had worked for the industry for many years knew the ins and outs of tobacco policy better than most government officials, giving them an information advantage. Information asymmetry and dependence on information from the industry make it more difficult for the government to make independent, balanced policy decisions (Coglianese, Zeckhauser, \& Parson, 2004).

What stands out is the perseverance of the industry lobby, which relentlessly voiced the same arguments and concerns over and over, exploiting diverse routes of influence. These included politicians, bureaucrats in various ministries, and third party contacts, especially the powerful employers' organisation VNO-NCW. They knew whom to contact at which point, and they approached policymakers at all levels, from low-ranking civil servants to ministers, and even the prime minister. The lobbying game was sometimes played simultaneously at national, European, and global levels.

Around 1996, when Health Minister Els Borst distanced herself from the tobacco industry, the industry lost some of its grip on the government, and moved to expand its influence through other parties. It forged coalitions with Royal Dutch Hospitality, smokers' rights groups, and the ventilation industry to fend off hospitality bans, and with supermarket and retail organisations to prevent sale restrictions. In later years $\mathrm{VNO}-\mathrm{NCW}$ tried to normalise contacts with the Ministry of Health and to reinstate the practice of involving the industry in conceptualising and drafting tobacco control policy. They were somewhat successful between 2007 and 2012 under the ministerships of Klink and Schippers, but more recently, public outrage over the many violations of Article 5.3 FCTC tarnished the reputation of the Dutch tobacco industry and made direct contact between the government and the industry increasingly difficult. One former tobacco industry lobbyist lamented about more recent years, "the antitobacco lobby was much more effective than the tobacco lobby, much more effective, mainly because they have been very successful in holding off every contact between the government and the tobacco industry." 46 


\section{Notes}

1. Philip Morris, producer of best-selling brand Marlboro, became the market leader in the Netherlands around 1986.

2. Proceedings II, 1995-1996, Kamervragen, Aanhangsel 1428.

3. https://www.industrydocumentslibrary.ucsf.edu/tobacco/

4. Rinnooy Kan was proclaimed by the press as the most influential person in the Netherlands in the years 2007-2009.

5. Interview, 6 November 2015.

6. Interview, 6 October 2015.

7. Vrij Nederland, 23 November 2002.

8. Another example of the importance of the CDA to the industry was Rob Koreneef. He started in 1991 as political assistant to a CDA member of parliament. After that, he followed a similar career path as Wilhelmus: first working as public affairs consultant at Burson-Marsteller and then moving on to do similar work for tobacco manufactures (Imperial Tobacco and Philip Morris).

9. For example, Martin Bril, Drs. P., Max van Rooy, Martin van Amerongen, Jan Mulder (a non-smoker), and Theodor Holman.

10. This argument has become hollow over the years, as the Netherlands no longer had a noticeable cigarette manufacturing industry (see Chap. 5 for more details).

11. In Dutch: Wet op de Investeringsrekening (WIR). It was set up in 1978 by the Ministry for Economic Affairs to stimulate businesses to invest in company assets such as machines, and was in force until 1988.

12. Comparable to a sum of about $€ 6$ million in 2016.

13. Illustrative of the close links with the trade ministry is the fact that Jules Wilhelmus, information officer for that ministry between 1982 and 1987 , left to work for some years with Burson-Marsteller, Philip Morris' main PR bureau, and continued his career as director of corporate affairs for Philip Morris from 1995 until 2005.

14. Minister of Economic Affairs from 1989 to 1994.

15. Interview, 26 April 2016.

16. Proceedings II, 1996-1997, 24743, nr. 3, p. 8.

17. Dutch: bestuurlijk overleg.

18. Dutch: ambtelijk overleg.

19. Parliamentary Papers II, 1982-1983, 17600, hoofdstuk XIII, nr. 36.

20. Proceedings II, 10 February $1983,47^{\mathrm{c}}$ meeting, p. 2241.

21. Proceedings I, 8 June $1983,31^{\mathrm{e}}$ meeting, p. 862.

22. See also Chap. 5 on the "better regulation" movement in the Netherlands.

23. Proceedings II, 31 May 2001, TK 82, 5216; Proceedings I, 26 March 2002, 24-1255.

24. https://www.industrydocumentslibrary.ucsf.edu/tobacco/ 
25. Parliamentary Papers II, 2009-2010, kv-2009Z17997.

26. Interview, 6 October 2015.

27. The Dutch Excise Duty Act dates from 1921 and has been modernised in 1961 and 1991.

28. Interview, 6 November 2015.

29. See for examples of such contacts in 2008 and 2010: https://www.industrydocumentslibrary.ucsf.edu/tobacco/docs/\#id=xkxb0191

30. Interview, 22 February 2017.

31. See (SSI \& Toet, 1972-1996) for a collection of correspondence between the industry and the government on tobacco taxation.

32. In 2004 there was a larger tax increase to support the workplace smoking ban. In 2008, with the introduction of the smoking ban in bars and restaurants, another higher-than-usual increase was realised. In 2013, tax increases resulted in consumer price increases of more than $10 \%$ for both cigarettes and roll-your-own tobacco.

33. Proceedings II, 1991-1992, 22351, nr. 4.

34. Parliamentary Papers II, 1991-1992, 22351, nrs. 5 and 7.

35. Proceedings II, 1983-1984, 18139, nr. 4.

36. Proceedings II, 24743 , nr. 3 , p. 4.

37. Interview with a former civil servant on 1 February 2017.

38. Proceedings II, 22 December 1993, 41-3246.

39. Proceedings II, 1997-1998, Annex 891.

40. Proceedings II, 1993-1994, 23400 XVI, 78, p. 6.

41. Interview on 18 November 2015.

42. Recommendation 2.1 of the implementation guidelines for Article 5.3 FCTC.

43. Parliamentary Papers II, 2005-2006, 22894, nr. 83.

44. https://www.industrydocumentslibrary.ucsf.edu/tobacco/

45. Such powerful networks that protect business interests are common in the Netherlands, not only in tobacco but in other areas such as education and agriculture as well (Trappenburg, 2005).

46. Interview on 22 February 2017.

\section{REFERENCES}

Algemene Rekenkamer. (2012). Bestrijding van accijnsfraude bij alcohol en tabak. EU-beleid: naleving en effecten. Den Haag: Sdu Uitgevers.

Andeweg, R. B., \& Irwin, G. A. (2009). Governance and politics of the Netherlands (3rd ed.). Hampshire: Palgrave Macmillan.

ARISE. (1995a). Living is more than surviving: The contribution of pleasure to everyday life-International media coverage 1995/96. British American Tobacco Records, Bates No. 500853324-500853394. Retrieved from https:// www.industrydocumentslibrary.ucsf.edu/tobacco/docs/spmv0211 
ARISE. (1995b). A summary of the workshop held in April 1995. Living is more than surviving. RJ Reynolds Records, Bates No. 511818234-511818241. Retrieved from https://www.industrydocumentslibrary.ucsf.edu/tobacco/ docs/ppnm0089

Baltesen, F., \& Rosenberg, E. (2009, June 22). Big tobacco pays Dutch opposition to smoking ban. NRC Handelsblad. Retrieved from http://vorige.nrc.nl/ international/article2278646.ece/Big_tobacco_pays_Dutch_opposition_to_ smoking_ban

Blankert, J. (1997). Wijzigingen tabakswet. Dutch Tobacco Industry Collection, Bates No. JB2074. Retrieved from https://www.industrydocumentslibrary. ucsf.edu/tobacco/docs/xjdp0219

Blankert, J. (1999). [Letter to Jorritsma]. Dutch Tobacco Industry Collection, Bates No. JB2377. Retrieved from https://www.industrydocumentslibrary.ucsf. $\mathrm{edu} /$ tobacco/docs/fsdp0219

Bonhoff, E. J. (2002). Brief van het ministerie van VWS aan de Stichting Sigarettenindustrie over het Tabaksontmoedigingsbeleid. Dutch Tobacco Industry Collection, Bates No. JB3527.

Borst-Eilers, E. (1996). Verslag overleg tabaksontmoedigingsbeleid. Dutch Tobacco Industry Collection, Bates No. JB2069. Retrieved from https://www.industrydocumentslibrary.ucsf.edu/tobacco/docs/txdp0219

Bouma, J. (2001). Het rookgordijn: De macht van de Nederlandse tabaksindustrie. Amsterdam: Veen.

Bouma, J. (2012, February 21). Tabakslobby op schoot bij minister Schippers. Trouw. Retrieved from http://www.trouw.nl/tr/nl/4516/Gezondheid/article/detail/ 3193743/2012/02/21/Tabakslobby-op-schoot-bij-minister-Schippers.dhtml

Braam, S., \& Van Woerden, I. (2013, juni 27). De laatste vriend van de sigaret. Vrij Nederland.

Bruinsma, J. (1996, October 30). Alleen Jet Nijpels wijzigde standpunt na bezoek tabaksindustrie. Kamerleden ontkennen invloed lobby, de Volkskrant, p. 7. Retrieved from https://www.industrydocumentslibrary.ucsf.edu/tobacco/ docs/thcp0219

Coglianese, C., Zeckhauser, R., \& Parson, E. (2004). Seeking truth for power: Informational strategy and regulatory policy making. Faculty Research Working Papers Series Harvard University, John F. Kennedy School of Government, RWP04-021.

De Blij, B. (1996a). Letter to Wijers. Dutch Tobacco Industry Collection, Bates No. JB2517. Retrieved from https://www.industrydocumentslibrary.ucsf.edu/ tobacco/docs/mxwp0219

De Blij, B. (1996b). Tabaksontmoedigingsbeleid. Dutch Tobacco Industry Collection, Bates No. JB2695. Retrieved from https://www.industrydocumentslibrary.ucsf.edu/tobacco/docs/gnfp0219

De Goeij, J. I. M. (2006). [Letter to VNK]. Dutch Tobacco Industry Collection, Bates No. JB3059. Retrieved from https://www.industrydocumentslibrary. ucsf.edu/tobacco/docs/jtwn0217 
De Jager, J. H. (2008). Beleidsvoornemens tabaksontmoediging. Dutch Tobacco Industry Collection, Bates No. JB0562. Retrieved from https:// www.industrydocumentslibrary.ucsf.edu/tobacco/docs/hkxb019l

De Wolff, F. A. (1994a). Comments on the OSHA proposed rule on indoor air quality, April 5. Dutch Tobacco Industry Collection, Bates No. JB1177. Retrieved from https://www.industrydocumentslibrary.ucsf.edu/tobacco/ docs/hkxp0219

De Wolff, F. A. (1994b). Risico van longkanker door passief roken nog onbewezen. Nederlands Tijdschrift voor Geneeskunde, 138, 503-506.

Dortland, R. (2005). Brief van het ministerie van VWS aan de Stichting Sigarettenindustrie betreffende de Tabakswet. Dutch Tobacco Industry Collection, Bates No. JB3525. Retrieved from https://www.industrydocumentslibrary.ucsf.edu/tobacco/docs/fswn0217

Emmelot, P. (1979). Wetenschappelijke Adviesraad Roken en Gezondheid (WARG). Dutch Tobacco Industry Collection, Bates No. JB1400. Retrieved from https:// www.industrydocumentslibrary.ucsf.edu/tobacco/docs/jqgp0219

Engelsman, E. (1992). Mondeling overleg tabaksontmoedigingsbeleid. Dutch Tobacco Industry Collection, Bates No. JB2031. Retrieved from https://www. industrydocumentslibrary.ucsf.edu/tobacco/docs/rmfp0219

EPA. (1992). Respiratory bealth effects of passive smoking (also known as exposure to secondhand smoke or Environmental Tobacco Smoke-ETS). Washington, DC: U.S. Environmental Protection Agency (EPA).

Evenhuis, A. (1988). Reclamecode sigaretten en shag Dutch Tobacco Industry Collection, Bates No. JB2182. Retrieved from https://www.industrydocumentslibrary.ucsf.edu/tobacco/docs/fndp0219

Forces USA. (1998). The speakers of the 1997 Smokepeace International Conference. Philip Morris Collection, Bates No. 2073643759-2073643760. Retrieved from https://www.industrydocumentslibrary.ucsf.edu/tobacco/ docs/nhbb0088

Gemeente Bergen op Zoom. (1996). Accijnsverhoging op tabaksproducten [letter to the prime minister]. Dutch Tobacco Industry Collection, Bates No. JB2646. Retrieved from https://www.industrydocumentslibrary.ucsf.edu/tobacco/ docs/xywp0219

GfK Great Britain. (1998). ETS world report Philip Morris 1998. Philip Morris Records, Bates No. 2065221475-2065221544. Retrieved from http://legacy. library.ucsf.edu/tid/fnq $90 \mathrm{~g} 00 / \mathrm{pdf}$

Goldberg, H. (1999a). Accommodation programs. Philip Morris Collection, Bates No. 2072577224-2072577238. Retrieved from http://legacy.library.ucsf. edu/tid/otq59h00

Goldberg, H. (1999b). International accommodation programs. Philip Morris Collection, Bates No. 2074399542-2074399568. Retrieved from http://legacy.library.ucsf.edu/tid/thpl 1 h00 
Hamers, J., \& Vermeulen, A. (1996). Tabakaccijns [letter to the prime minister]. Dutch Tobacco Industry Collection, Bates No. JB2670. Retrieved from https:// www.industrydocumentslibrary.ucsf.edu/tobacco/docs/qpwp0219

Hoogervorst, H. (2003a). Regeling lijsten tabaksingrediënten [letter to SSI]. Dutch Tobacco Industry Collection, Bates No. JB3259. Retrieved from https:// www.industrydocumentslibrary.ucsf.edu/tobacco/docs/nybn0217

Hoogervorst, H. (2003b). Regulier overleg tabaksontmoedigingsbeleid. Dutch Tobacco Industry Collection, Bates No. JB0278. Retrieved from https://www. industrydocumentslibrary.ucsf.edu/tobacco/docs/sjhb0191

Hoogervorst, H. (2006a). Antwoordbrief aan VNK en SSI. Dutch Tobacco Industry Collection, Bates No. JB0412.

Hoogervorst, H. (2006b). Brief van het ministerie van VWS aan de Vereniging Nederlandse Kerftabakindustrie. Dutch Tobacco Industry Collection, Bates No. JB3333. Retrieved from https://www.industrydocumentslibrary.ucsf.edu/ tobacco/docs/ftwn0217

Horeca Nederland. (2002). Overleg Tabakswet [letter to Borst]. Dutch Tobacco Industry Collection, Bates No. JB3517. Retrieved from https://www.industrydocumentslibrary.ucsf.edu/tobacco/docs/flwn0217

Huijts, P. H. A. M. (2009). Gesprek 24 Augsutus jl. Dutch Tobacco Industry Collection, Bates No. JB061l. Retrieved from https://www.industrydocumentslibrary.ucsf.edu/tobacco/docs/hnxb0191

Jha, P., \& Chaloupka, F. J. (2000). The economics of global tobacco control. BMJ: British Medical Journal, 321(7257), 358-361.

Kalis, A. W. (2002). Consultatie inzake inwerkingtreding van gewijzigde Tabakswet. Dutch Tobacco Industry Collection, Bates No. JB3519. Retrieved from https:// www.industrydocumentslibrary.ucsf.edu/tobacco/docs/jkcn0217

Kalis, A. W. (2003). Regulier overleg tabaksontmoedigingsbeleid. Dutch Tobacco Industry Collection, Bates No. JB0272. Retrieved from https://www.industrydocumentslibrary.ucsf.edu/tobacco/docs/mjhb0191

Klijn, W., \& Toet, R. L. J. (1991). [Letter to Ministry of Finance]. Dutch Tobacco Industry Collection, Bates No. JB2781. Retrieved from https://www.industrydocumentslibrary.ucsf.edu/tobacco/docs/mtwp0219

Klink, A. (2007). Tabaksontmoedigingsbeleid (letter to SSI). Dutch Tobacco Industry Collection, Bates No. JB0454. Retrieved from https://www.industrydocumentslibrary.ucsf.edu/tobacco/docs/qzhb0191

Kok, W. (1996, September 2). Verhoging tabakaccijns. Retrieved from https:// www.industrydocumentslibrary.ucsf.edu/tobacco/docs/rywp0219

Korteweg, A., \& Huisman, E. (2016). Lobbyland: De geheime krachten in Den Haag. Amsterdam: De Geus.

Loubeau, P. (2014). An exploratory review of illicit tobacco trade in the Netherlands. Den Haag: Alliantie Nederland Rookvrij. 
Luyendijk, J., Verkade, T., \& Heck, W. (2010). Het lobbywerk dat níet op de cv’s van politici staat. Retrieved from https://www.nrc.nl/nieuws/2010/11/22/ het-lobbywerk-dat-niet-op-de-cvs-van-politici-staat-11972720-a865044

Mantel, A., \& de Wolf, P. (1983). Marktkoncentratie en internatialisatie in de Nederlandse tabaksindustrie. Tijdschrift voor Politieke Ekonomie, 6, 34-56.

Marres, E. A. H., \& Toet, R. L. J. (1987). Voorstellen van de SSI en de VNK ter aanpassing van de reclamecode. Dutch Tobacco Industry Collection, Bates No. JB2179. Retrieved from https://www.industrydocumentslibrary.ucsf.edu/ tobacco/docs/tmdp0219

Mindell, J. S., \& Whynes, D. K. (2000). Cigarette consumption in The Netherlands 1970-1995: Does tax policy encourage the use of hand-rolling tobacco? European Journal of Public Health, 10(3), 214-219. https://doi.org/10.1093/ eurpub/10.3.214

Ministerie van Economische Zaken. (1982a). Ontmoedigingsbeleid tabaksgebruik. Dutch Tobacco Industry Collection, Bates No. JB2449. Retrieved from https:// www.industrydocumentslibrary.ucsf.edu/tobacco/docs/\#id=fyfp0219

Ministerie van Economische Zaken. (1982b). Ontmoedigingsbeleid tabaksgebruik en alcoholbeleid. Dutch Tobacco Industry Collection, Bates No. JB2447. Retrieved from https://www.industrydocumentslibrary.ucsf.edu/tobacco/ docs/mfwp0219

Ministerie van Economische Zaken. (1984). Wetsontwerp ter verlaging van accijns op sigaretten i.v.m. eenmalige accijnsvrije prijsverhoging. Dutch Tobacco Industry Collection, Bates No. JB2221. Retrieved from https://www.industrydocumentslibrary.ucsf.edu/tobacco/docs/snfp0219

Ministerie van Economische Zaken. (1992). [Brief van het ministerie van EZ aan de NVS betreft sigarenaccijns]. Dutch Tobacco Industry Collection, Bates No. JB2464. Retrieved from https://www.industrydocumentslibrary.ucsf.edu/ tobacco/docs/hgwp0219

Ministerie van Economische Zaken. (1995). Tussenrapportage Werkgroep Afspraken Tabaksbeleid. Dutch Tobacco Industry Collection, Bates No. JB1037.

Ministerie van Economische Zaken. (2009a). E-mails over plain packaging. Dutch Tobacco Industry Collection, Bates No. JB3821. Retrieved from https://www. industrydocumentslibrary.ucsf.edu/tobacco/docs/rrbn0217

Ministerie van Economische Zaken. (2009b). RE: Generieke verpakkingen voor tabaksproducten. Dutch Tobacco Industry Collection, Bates No. JB0505. Retrieved from https://www.industrydocumentslibrary.ucsf.edu/tobacco/ docs/mtxb0191

Ministerie van Economische Zaken. (2009c). Stand van zaken invoering "plain packaging" in de Aanbeveling van de Raad inzake rookvrije ruimten. Dutch Tobacco Industry Collection, Bates No. JB0512. Retrieved from https://www. industrydocumentslibrary.ucsf.edu/tobacco/docs/nzxb0191 
Ministerie van Financiën. (2011). Various e-mails. Dutch Tobacco Industry Collection, Bates No. JB0402. Retrieved from https://www.industrydocumentslibrary.ucsf.edu/tobacco/docs/mrhb0191

Monkhorst, T. (2002). Brief aan het ministerie van VWS over tabaksbeleid. Dutch Tobacco Industry Collection, Bates No. JB3528. Retrieved from https://www. industrydocumentslibrary.ucsf.edu/tobacco/docs/xncn0217

Nagelhout, G. E., Levy, D. T., Blackman, K., Currie, L., Clancy, L., \& Willemsen, M. C. (2012). The effect of tobacco control policies on smoking prevalence and smoking-attributable deaths. Findings from the Netherlands SimSmoke tobacco control policy simulation model. Addiction, 107(2), 407-416. https:// doi.org/10.1111/j.1360-0443.2011.03642.x

National Research Council. (1986). Environmental tobacco smoke: Measuring exposure and assessing health effects. Washington, DC: National Academy Press.

Nellen, M. E. A. H., \& De Blij, B. A. I. M. (1999). The "success" of Philip Morris' campaign on environmental tobacco smoke in the Netherlands. Tobacco Control, 8(2), 221-222. https://doi.org/10.1136/tc.8.2.221a

NVK, NVS, SSI \& Philip Morris Benelux. (2010). [Letter to Huijts]. Dutch Tobacco Industry Collection, Bates No. JB0562. Retrieved from https://www. industrydocumentslibrary.ucsf.edu/tobacco/docs/\#id=hkxb0191

NVS, VNK \& SSI. (1990). [Brieven van de NVS, VNK en SSI aan het ministerie van VWS en het ministerie van EZ]. Dutch Tobacco Industry Collection, Bates No. JB2347. Retrieved from https://www.industrydocumentslibrary.ucsf. edu/tobacco/docs/nqdp0219

O’NeillI, K., Brunnemann, K. D., Dodet, B., \& Hoffmann, D. (1987). Passive smoking: Environmental carcinogens. IARC scientific publications (Vol. 9). Lyon: International Agency for Research on Cancer (IARC).

Philip Morris. (1979). Smoking \& health-Five year plan. Philip Morris Records, Bates No. 2501020542-2501020686. Retrieved from https://www.industrydocumentslibrary.ucsf.edu/tobacco/docs/yfhl0000

Philip Morris. (1989). Several lobby letters about tax increase. Dutch Tobacco Industry Collection, Bates No. JB2223. Retrieved from https://www.industrydocumentslibrary.ucsf.edu/tobacco/docs/gydp0219

Philip Morris. (1994). 1994 Action plans Benelux. Philip Morris Records, Bates No. 2501318291-2501318294. Retrieved from https://www.industrydocumentslibrary.ucsf.edu/tobacco/docs/pnbj0115

Philip Morris. (1996a). Corporate Affairs 1996/1997 The Netherlands. Philip Morris Records, Bates No. 2501076006-2501076023. Retrieved from https:// www.industrydocumentslibrary.ucsf.edu/tobacco/docs/nzj10112

Philip Morris. (1996b). Verhoging van de accijns op tabaksproducten. Dutch Tobacco Industry Collection, Bates No. JB2661. Retrieved from https://www. industrydocumentslibrary.ucsf.edu/tobacco/docs/hpwp0219

Remes, D. (1988). The PM EEC/EEMA ETS Project-Draft-20 Feb 1988. Ness Motley Law Firm Documents, Bates No. 2501474253-2501474259. 
Retrieved from https://www.industrydocumentslibrary.ucsf.edu/tobacco/ docs/psly0042

Rijsterborgh, I. J. (2017). The importance of the tobacco industry for the Dutch economy. Maastricht: Maastricht University.

Rinnooy-Kan, A. H. G. (1994). Letter to VWS. Dutch Tobacco Industry Collection, Bates No. JB2591. Retrieved from https://www.industrydocumentslibrary. ucsf.edu/tobacco/docs/jmwp0219

Rinnooy-Kan, A. H. G. (1995a). Letter to Minister Wijers. Dutch Tobacco Industry Collection, Bates No. JB2589. Retrieved from https://www.industrydocumentslibrary.ucsf.edu/tobacco/docs/hkfp0219

Rinnooy-Kan, A. H. G. (1995b). Letter to VWS. Dutch Tobacco Industry Collection, Bates No. JB2590. Retrieved from https://www.industrydocumentslibrary. ucsf.edu/tobacco/docs/xmwp0219

RJ Reynolds. (1978). Chapter 1 smoking and health. RJ Reynolds Records, Bates No. 500534913-500534931. Retrieved from https://www.industrydocumentslibrary.ucsf.edu/tobacco/docs/llmf0099

Roelofs, W. J. (1996a). Letter to VWS. Dutch Tobacco Industry Collection, Bates No. JB2175. Retrieved from https://www.industrydocumentslibrary.ucsf. edu/tobacco/docs/pmdp0219

Roelofs, W. J. (1996b). Tabaksontmoedigingsbeleid. Dutch Tobacco Industry Collection, Bates No. JB2687. Retrieved from https://www.industrydocumentslibrary.ucsf.edu/tobacco/docs/pqwp0219

Roelofs, W. J. (1998). Tabaksontmoedigingsbeleid. Dutch Tobacco Industry Collection, Bates No. JB2391. Retrieved from https://www.industrydocumentslibrary.ucsf.edu/tobacco/docs/psdp0219

Roelofs, W. J. (2000a). [Letter to Minister Borst]. Dutch Tobacco Industry Collection, Bates No. JB2402. Retrieved from https://www.industrydocumentslibrary.ucsf.edu/tobacco/docs/xtdp0219

Roelofs, W. J. (2000b). [Letter to Prime Minister Kok]. Dutch Tobacco Industry Collection, Bates No. JB0349. Retrieved from https://www.industrydocumentslibrary.ucsf.edu/tobacco/docs/hyhb0191

Roessingh, H. K. (1976). Inlandse tabak: Expansie en contractie van een handelsgewas in de 17e en 18e eeuw in Nederland (Doctoral dissertation), Landbouw Hogeschool, Wageningen.

Roos, M. J. (1985). Tabakswet. Dutch Tobacco Industry Collection, Bates No. JB2433. Retrieved from https://www.industrydocumentslibrary.ucsf.edu/ tobacco/docs/pzdp0219

Schama, S. (1987). The embarrassment of riches: An interpretation of Dutch culture in the Golden Age. New York: Vintage Books.

Schipper, J. W. (1999a). [Brief van Philip Morris aan het ministerie van Economische Zaken betreft Overleg d.d. 14 juni 1999]. Dutch Tobacco Industry Collection, Bates No. JB2419. Retrieved from https://www.industrydocumentslibrary.ucsf.edu/tobacco/docs/ztdp0219 
Schipper, J. W. (1999b). [Letter to Minister Jorritsma]. Dutch Tobacco Industry Collection, Bates No. JB2111. Retrieved from https://www.industrydocumentslibrary.ucsf.edu/tobacco/docs/gkdp0219

Schippers, E. J. (2010). Beleidsvoornemens tabaksontmoediging [letter to SSI and VNK]. Dutch Tobacco Industry Collection, Bates No. JB0562. Retrieved from https://www.industrydocumentslibrary.ucsf.edu/tobacco/docs/hkxb0191

Schraven, J. H. (2001a). [Letter VNO-NCW to Borst-Eilers]. Dutch Tobacco Industry Collection, Bates No. JB3560. Retrieved from https://www.industrydocumentslibrary.ucsf.edu/tobacco/docs/njwn0217

Schraven, J. H. (2001b). Regulier overleg tabaksontmoedigingsbeleid. Dutch Tobacco Industry Collection, Bates No. JB0271. Retrieved from https://www. industrydocumentslibrary.ucsf.edu/tobacco/docs/ljhb019l

Schraven, J. H. (2003a). [Letter VNO-NCW to Ross-van Dorp]. Dutch Tobacco Industry Collection, Bates No. JB3557. Retrieved from https://www.industrydocumentslibrary.ucsf.edu/tobacco/docs/sxdn0217

Schraven, J. H. (2003b). Regulier overleg tabaksontmoedigingsbeleid. Dutch Tobacco Industry Collection, Bates No. JB0269. Retrieved from https://www. industrydocumentslibrary.ucsf.edu/tobacco/docs/jjhb0191

Smid, E. (2007). [Letter to Ministry of VWS]. Dutch Tobacco Industry Collection, Bates No. JB3477. Retrieved from https://www.industrydocumentslibrary. ucsf.edu/tobacco/docs/gffn0217

Smith, E. A. (2007). 'It's interesting how few people die from smoking': Tobacco industry efforts to minimize risk and discredit health promotion. The European Journal of Public Health, 17(2), 162-170. https://doi.org/10.1093/eurpub/ckl097

Smith, E. A., \& Malone, R. E. (2007). We will speak as the smoker: The tobacco industry's smokers' rights groups. European Journal of Public Health, 17(3), 306-313. https://doi.org/10.1093/eurpub/ck1244

SSI. (1983). Ontmoedigingsbeleid tabak. Dutch Tobacco Industry Collection, Bates No. JB2225. Retrieved from https://www.industrydocumentslibrary.ucsf. edu/tobacco/docs/\#id=hydp0219

SSI. (1984). [Letter to Ministry of Economic Affairs]. Dutch Tobacco Industry Collection, Bates No. JB3980. Retrieved from https://www.industrydocumentslibrary.ucsf.edu/tobacco/docs/zzwp0219

SSI. (1991). [Correspondence with Ministries of Economic Affairs and Finance]. Dutch Tobacco Industry Collection, Bates No. JB2354. Retrieved from https:// www.industrydocumentslibrary.ucsf.edu/tobacco/docs/tqdp0219

SSI. (2001). [Letter to ministries of VWS and Economic Affairs]. Dutch Tobacco Industry Collection, Bates No. JB3498. Retrieved from https://www.industrydocumentslibrary.ucsf.edu/tobacco/docs/pmen0217

SSI. (2002). Tabaksontmoedigingsbeleid [Letter to Bomhoff] Dutch Tobacco Industry Collection, Bates No. JB3526. Retrieved from https://www.industrydocumentslibrary.ucsf.edu/tobacco/docs/hncn0217 
SSI \& SNK. (1984). Jaaroverzicht 1983. Dutch Tobacco Industry Collection, Bates No. JB2268. Retrieved from https://www.industrydocumentslibrary.ucsf. edu/tobacco/docs /\#id=nfgp0219

SSI, \& Toet, R. L. (1972-1996). Collection of industry lobby letters about tobacco price and taxation. Dutch Tobacco Industry Collection, Bates No. JB2000. Retrieved from https://www.industrydocumentslibrary.ucsf.edu/tobacco/docs/fxfp0219

SSI \& VNK. (2007). Overleg met VNO-NCW en de tabaksindustrie (SSI, VNK en NVS). Dutch Tobacco Industry Collection, Bates No. JB0454. Retrieved from https://www.industrydocumentslibrary.ucsf.edu/tobacco/docs/qzhb0191

Taylor, P. (1984). The smoke ring: Tobacco, money \& multinational politics. London: Sphere Books.

Toet, R. L. J. (1994). Reclamecode voor tabaksprodukten [letter]. Dutch Tobacco Industry Collection, Bates No. JB2533. Retrieved from https://www.industrydocumentslibrary.ucsf.edu/tobacco/docs/kjwp0219

Trappenburg, M. (2005). Gezondheidszorg en democratie [inaugural lecture]. Rotterdam: Erasmus University.

UICC. (1996). Philip Morris campaign on passive smoking. Dutch Tobacco Industry Collection, Bates No. JB1186. Retrieved from https://www.industrydocumentslibrary.ucsf.edu/tobacco/docs/kkxp0219

US Surgeon General. (1986). The health consequences of involuntary smoking. Rockville: USDHHS.

Van Baal, P. H. M., Brouwer, W. B. F., Hoogenveen, R. T., \& Feenstra, T. L. (2007). Increasing tobacco taxes: A cheap tool to increase public health. Health Policy, 82(2), 142-152. https://doi.org/10.1016/j.healthpol.2006.09.004

Van de Mortel, J. L. P. M. (1996). Reactie op de concept nota inzake tabaksontmoedigingsbeleid. Dutch Tobacco Industry Collection, Bates No. JB2518. Retrieved from https://www.industrydocumentslibrary.ucsf.edu/tobacco/ docs/nxwp0219

Van de Mortel, P. M., \& Roelofs, W. J. (1996). Concept-notitie interdepartementale werkgroep accijns. Dutch Tobacco Industry Collection, Bates No. JB2070. Retrieved from https://www.industrydocumentslibrary.ucsf.edu/tobacco/ docs/zxdp0219

Van de Wetering, C. (2010). Niek Jan van Kesteren, directeur VNO-NCW. De onzichtbare onderhandelaar. Retrieved from http://www.pm.nl/artikel/640/ niek-jan-van-kesteren-de-onzichtbare-onderhandelaar

Van der Bles, W. (1996). Boze Wijers treedt toe tot het gezelschap antirookmagiërs. Retrieved from http://www.trouw.nl/tr/nl/5009/Archief/ article/detail/2632148/1996/09/06/Boze-Wijers-treedt-toe-tot-hetgezelschap-anti-rookmagiers.dhtml

Van Gelder, H. (1990). Rokers maken een vuist. Retrieved from http://www.nrc. $\mathrm{nl} /$ nieuws/1990/01/08/rokers-maken-een-vuist-6921081-al190151

Van Hoogstraten, S. (1997a). Besluitenlijst overleg 'Aanscherping RvT'. Dutch Tobacco Industry Collection, Bates No. JB2196. Retrieved from https://www. industrydocumentslibrary.ucsf.edu/tobacco/docs/zxfp0219 
Van Hoogstraten, S. (1997b). Gewijzigde definitieve verslag van de Hoordag op 2 September. Dutch Tobacco Industry Collection, Bates No. JB2079. Retrieved from https://www.industrydocumentslibrary.ucsf.edu/tobacco/ docs/jpxp0219

Van Londen, J. (1980). Voorstellen ICBT inzake beperking tabakreclame en verkooppunten tabaksproducten. Dutch Tobacco Industry Collection, Bates No. JB1801. Retrieved from https://www.industrydocumentslibrary.ucsf.edu/ tobacco/docs/ffdp0219

Van Oosten, R. (1996). Introductie landelijke belangenvereniging van tabaksdustributeurs Nederland. Dutch Tobacco Industry Collection, Bates No. JB2671. Retrieved from https://www.industrydocumentslibrary.ucsf.edu/tobacco/ docs/pggp0219

Van Proosdij, C. (1957). Smoking, its influence in the individual and its role in social medicine [Roken: Een individueel-en sociaalgeneeskundige studie]. $\mathrm{PhD}$ thesis, University of Amsterdam, Amsterdam.

Van Ronkel, H. (1996). Overheid schendt gemaakte afspraken. Dutch Tobacco Industry Collection, Bates No. JB2174. Retrieved from https://www.industrydocumentslibrary.ucsf.edu/tobacco/docs/zqfp0219

VNK. (1991). [Brief van VNK aan het ministerie van EZ betreft Accijnsbrieven SSI/ VNK]. Dutch Tobacco Industry Collection, Bates No. JB2780. Retrieved from https://www.industrydocumentslibrary.ucsf.edu/tobacco/docs/ltwp0219

VNK. (2011). [E-mails about visit to factory]. Dutch Tobacco Industry Collection, Bates No. JB3922. Retrieved from https://www.industrydocumentslibrary. ucsf.edu/tobacco/docs/mhcn0217

VNK \& Ministry of Health. (2009). [various emails about VNK company day meeting]. Dutch Tobacco Industry Collection, Bates No. JB0066. Retrieved from https://www.industrydocumentslibrary.ucsf.edu/tobacco/docs/pmgb0191

VNK, NVS, SSI, \& Philip Morris Benelux. (2010). Betreft: Gesprek 5 oktober jl. inzake ontwikkelingen tabaksbeleid. Dutch Tobacco Industry Collection, Bates No. JB0533. Retrieved from https://industrydocuments.library.ucsf.edu/ tobacco/docs/lxxb0191

VNO-NCW. (201la). alcohol en tabak [email from VNO-NCW to EZ]. Dutch Tobacco Industry Collection, Bates No. JB0539. Retrieved from https://www. industrydocumentslibrary.ucsf.edu/tobacco/docs/rxxb0191

VNO-NCW. (2011b). Economische impact tabaksector. Dutch Tobacco Industry Collection, Bates No. JB0537. Retrieved from https://www.industrydocumentslibrary.ucsf.edu/tobacco/docs/pxxb0191

Volkskrant. (1996, September 6). VVD en CDA tegen hogere tabaksaccijns. Volkskrant. Retrieved from http://www.volkskrant.nl/vk/nl/2844/Archief/ archief/article/detail/425300/1996/09/06/VVD-en-CDA-tegen-hogeretabaksaccijns.dhtml

Vonk, T. H. (1995). Verhoging Tabaksaccijns. Dutch Tobacco Industry Collection, Bates No. JB2657. Retrieved from https://www.industrydocumentslibrary. ucsf.edu/tobacco/docs/tywp0219 
Voorlichtingsbureau Sigaretten en Shag. (1986). Jaaroverzicht. Dutch Tobacco Industry Collection, Bates No. JB2271. Retrieved from https://www.industrydocumentslibrary.ucsf.edu/tobacco/docs/qfgp0219

Vossenaar, T. (1997). Wetenschappelijke Adviesraad Roken en Gezondheid 1964-1997. Dutch Tobacco Industry Collection, Bates No. JB1390. Retrieved from https://www.industrydocumentslibrary.ucsf.edu/tobacco/docs/mhgp0219

VWS. (2003). Overleg 5/11/03 tabaksfabrikanten-VWS. Dutch Tobacco Industry Collection, Bates No. JB0266. Retrieved from https://www.industrydocumentslibrary.ucsf.edu/tobacco/docs/gjhb0191

Wever, L. J. S. (1988). Proces SVR/Tabaksindustrie. Dutch Tobacco Industry Collection, Bates No. JB0981. Retrieved from https://www.industrydocumentslibrary.ucsf.edu/tobacco/docs/yscp0219

Wever, L. J. S. (1992). Beperking tabaksreclame. Dutch Tobacco Industry Collection, Bates No. JB2156. Retrieved from https://www.industrydocumentslibrary. ucsf.edu/tobacco/docs/zldp0219

Wigand, J. S. (2005). Expert report on tobacco additives and validity of the Dutch decree on lists of tobacco ingredients. Dutch Tobacco Industry Collection, Bates No. JB0836. Retrieved from https://www.industrydocumentslibrary.ucsf. $\mathrm{edu} / \mathrm{tobacco} / \mathrm{docs} / \mathrm{glbp} 0219$

Wijers, G. J. (1996). Tabaksontmoedigingsbeleid. Dutch Tobacco Industry Collection, Bates No. JB2701. Retrieved from https://www.industrydocumentslibrary.ucsf.edu/tobacco/docs/mrwp0219

Wirthlin Group. (1996). ETS perceptions and attitudes: A review of available studies, Bates No. 2065210430-2065210477. Retrieved from http://legacy. library.ucsf.edu/tid/txf83c00

Open Access This chapter is licensed under the terms of the Creative Commons Attribution 4.0 International License (http://creativecommons.org/licenses/ by $/ 4.0 /$ ), which permits use, sharing, adaptation, distribution and reproduction in any medium or format, as long as you give appropriate credit to the original author(s) and the source, provide a link to the Creative Commons license and indicate if changes were made.

The images or other third party material in this chapter are included in the chapter's Creative Commons license, unless indicated otherwise in a credit line to the material. If material is not included in the chapter's Creative Commons license and your intended use is not permitted by statutory regulation or exceeds the permitted use, you will need to obtain permission directly from the copyright holder.

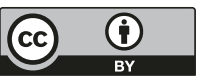

